\title{
Review \\ Genetic Landscape and Emerging Therapies in Uveal Melanoma
}

\author{
Rino S. Seedor *, Marlana Orloff and Takami Sato (D) \\ Department of Medical Oncology, Sidney Kimmel Cancer Center, Thomas Jefferson University, \\ Philadelphia, PA 19107, USA; Marlana.Orloff@jefferson.edu (M.O.); Takami.Sato@jefferson.edu (T.S.) \\ * Correspondence: Rino.Seedor@jefferson.edu; Tel.: +1-215-955-4687; Fax: +1-215-503-2715
}

check for updates

Citation: Seedor, R.S.; Orloff, M.; Sato, T. Genetic Landscape and Emerging Therapies in Uveal Melanoma. Cancers 2021, 13, 5503. https://doi.org/10.3390/ cancers 13215503

Academic Editor: David Wong

Received: 28 September 2021

Accepted: 30 October 2021

Published: 2 November 2021

Publisher's Note: MDPI stays neutral with regard to jurisdictional claims in published maps and institutional affiliations.

Copyright: (c) 2021 by the authors. Licensee MDPI, Basel, Switzerland. This article is an open access article distributed under the terms and conditions of the Creative Commons Attribution (CC BY) license (https:// creativecommons.org/licenses/by/ $4.0 /)$.
Simple Summary: Uveal melanoma is the most common primary intraocular malignancy in adults. Unfortunately, metastasis develops in up to $50 \%$ of cases and outcomes are poor for these patients. In this review, we discuss our current understanding of the unique genetic landscape of uveal melanoma, and the prognostic and potential therapeutic insight it can provide. By obtaining information on molecular and cytogenetic mutations, patients and their providers can gain important knowledge that may help with surveillance and treatment decisions, including clinical trial enrollment.

\begin{abstract}
Despite successful treatment of primary uveal melanoma, up to $50 \%$ of patients will develop systemic metastasis. Metastatic disease portends a poor outcome, and no adjuvant or metastatic therapy has been FDA approved. The genetic landscape of uveal melanoma is unique, providing prognostic and potentially therapeutic insight. In this review, we discuss our current understanding of the molecular and cytogenetic mutations in uveal melanoma, and the importance of obtaining such information. Most of our knowledge is based on primary uveal melanoma and a better understanding of the mutational landscape in metastatic uveal melanoma is needed. Clinical trials targeting certain mutations such as GNAQ/GNA11, BAP1, and SF3B1 are ongoing and promising. We also discuss the role of liquid biopsies in uveal melanoma in this review.
\end{abstract}

Keywords: uveal melanoma; metastatic uveal melanoma; genetic landscape; targeted therapy; treatment strategy

\section{Introduction}

Uveal melanoma (UM) is the most common primary intraocular malignancy in adults, with an estimated incidence of 5.2 per million population in the United States [1-3]. Up to $50 \%$ of UM patients will develop systemic metastasis despite successful treatment of the primary tumor, most commonly in the liver [4,5]. Overall metastatic disease portends a poor prognosis, with an estimated one-year survival of 15 to $67 \%$ and median overall survival ranges from 4 to 19 months [5-16].

Currently, there is no treatment for metastatic uveal melanoma (MUM) approved by the United States Food and Drug Administration. A recent systemic review of PubMed studies over the past 40 years demonstrated no statistically significant difference in overall survival between different treatment modalities for MUM; local therapies including intraarterial liver chemotherapy, isolated liver perfusion, and selective internal radiation therapy showed some advantage, although not statistically significant, in comparison to systemic therapies (chemotherapy, immunotherapy, immunosuppression, targeted therapy) [17]. Immunotherapy has dramatically improved outcomes for cutaneous melanoma patients, but a similar clinical benefit has not been seen in MUM [8]. Retrospective studies of immunotherapy in MUM patients reported low objective response rates ranging from $10-21 \%$ with combination ipilimumab and nivolumab, 3.6\% with anti- programmed cell death 1 (PD-1) antibodies, and 5\% with ipilimumab monotherapy [8,18-22]. Two recent prospective phase 
II studies of combination ipilimumab and nivolumab in MUM patients showed a median progression-free survival (PFS) of 3 and 5.5 months, median overall survival (OS) of 12.7 and 19.1 months, and overall response rate (ORR) of $11.5 \%$ and $18 \%[14,23]$. This is disappointing in comparison to the CHECKMATE067 study of combination ipilimumab and nivolumab in metastatic cutaneous melanoma patients achieving an impressive median OS of 72.1 months and ORR of $58 \%$ [24,25]. To improve immune response against metastatic uveal melanoma, various loco-regional approaches have been combined with systemic immune checkpoint inhibitors. There are many clinical trials that are ongoing that combine immunotherapy with other therapies in MUM in hopes of improving outcomes: isolated hepatic perfusion with ipilimumab and nivolumab (NCT04463368), percutaneous hepatic perfusion with ipilimumab and nivolumab (NCT04283890), arginine deprivation with ipilimumab and nivolumab (NCT03922880), radioembolization with Yttrium90 with ipilimumab and nivolumab (NCT02913417), immunoembolization with ipilimumab and nivolumab (NCT03472586), stereotactic radiosurgery with pembrolizumab (NCT02858869), entinostat with pembrolizumab (NCT02697630), and autologous CD8+ SLC45A2-specific T lymphocytes with cyclophosphamide, IL-2, and ipilimumab (NCT03068624).

The genetic landscape of cutaneous melanoma $(\mathrm{CM})$ appears to be quite different from uveal melanoma. The Cancer Genome Atlas (TCGA) has divided cutaneous melanoma into the four genomic subtypes of $B R A F, R A S$ (N/H/K), NF1, and Triple-WT (wild-type) [26]. These subtypes are based on the presence of $B R A F, N R A S$, and NF1 mutations in $52 \%, 28 \%$, and $14 \%$, respectively. With the exception of the Triple-WT subtype, a UV signature was noted in greater than $90 \%$ of samples. The tumor mutational burden was high in CM at 18 per $\mathrm{Mb}$ [26].

In contrast, the TCGA analysis on 80 primary UM has divided uveal melanoma into four different subtypes: two associated with poor-prognosis monosomy 3 and two with better-prognosis disomy 3 (Figure 1) [27,28]. Cluster 1 and 2 retained both copies of chromosome 3 and were enriched for $6 \mathrm{p}$ gain. Clusters 3 and 4 UMs were associated with monosomy 3. Gain of $8 \mathrm{q}$ was present in clusters 2, 3, and 4, with higher copy gains or amplifications in the higher number clusters. GNAQ, GNA11, BAP1, SF3B1, EIF1AX, CYSLTR2, SRSF2, MAPKAPK5, and PLCB4 were the nine genes found to be significantly mutated in primary UM. There was no UV radiation mutational signature and mutational burden was low at 1.1 per $\mathrm{Mb}$ [27].

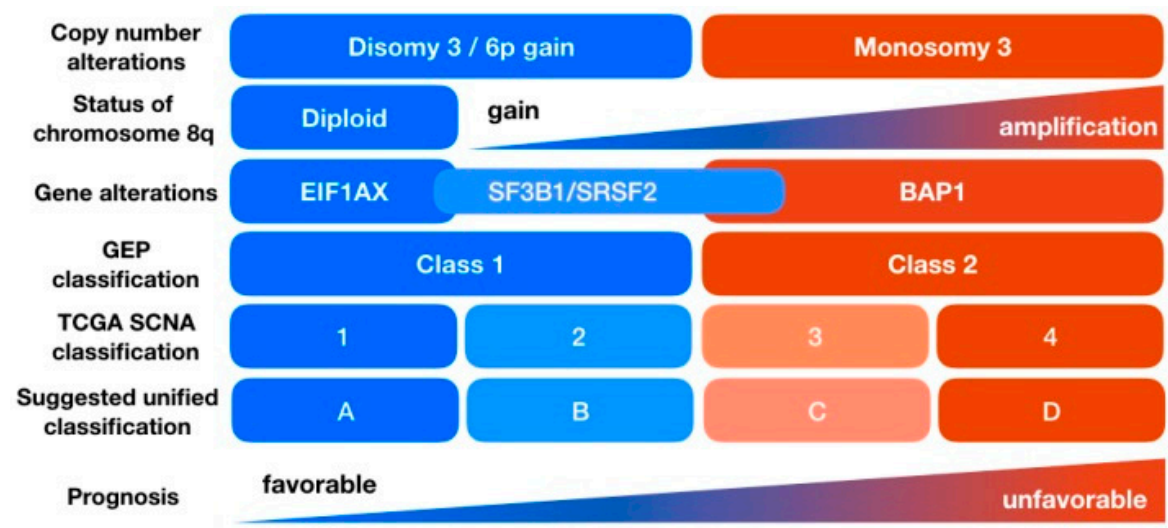

Figure 1. Schema of TCGA UM Subtypes. Reprinted from “Molecular Characteristics of Uveal Melanoma: Insights from the Cancer Genome Atlas (TCGA) Project," by Matheiu F. Bakhoum and Bita Esmaeli. 2019, Copyright 2019 by authors [28].

Similar to the TCGA analysis, other large genomic analyses of UM have also categorized UM tumors into four categories based on recurrent chromosomal aberrations and somatic mutations [27,29-31]. Interestingly the genomic analysis by Johansson et al. found all of their iris tumors to have genomic features associated with ultraviolet radiation damage [29]. This may be explained by the anterior position of the iris, resulting in direct exposure to sunlight that breaches the cornea. Another outlier is methyl-CpG-binding do- 
main 4 (MBD4) gene mutations, both germline and somatic loss of function variants, which lead to increased mutational burden and a better response to immunotherapy [32-34]. Overall though, compared to many other tumor types UM exhibit a relatively low degree of genomic instability and aneuploidy [35].

It is important to note that the DNA-based and RNA-based tests (including the test by Castle Biosciences) commonly utilized by ophthalmologists and oncologists analyze the primary eye specimen [27]. Genomic analyses of UM have been primarily on primary UM samples [29-31]. Analyses on metastatic UM have been small and few in number. Karlsson et al. specifically performed whole-genome sequencing (WGS) of 32 metastatic UM (6 subcutaneous and 26 liver) and found similar somatic mutations but more frequent broad copy number events compared to primary tumors from TCGA [36]. This included loss of chromosome 3,6q, and 17p, as well as gains of $5 p$ and $8 q$. Two of their tumors also had $C D K N 2 A$ deletions which are rarely seen in primary UM [36]. Likewise, genomic analyses that compared primary to metastatic UM noted enrichment of most somatic alterations, mainly in copy number changes of 6q (loss), 1q (gain), and 8q (gain) [33,37]. Loss of heterozygosity on chromosome 3 was never acquired during tumor progression or in metastases [33]. Unlike most other tumor types, UMs continues to genetically evolve as they progress from primary to metastatic disease, gaining more oncogenic mutations along the way [37-39]. When compared to liver metastases from CM, the genomic profiles seen in liver metastases from UM were very different [40]. Tumor mutational burden was low in liver UM compared to that of CM. MelanA expression was higher in UM compared to CM, but PD-L1 expression was lower $(<1 \%$ in $93 \%$ of the UM samples vs $73 \%$ in CM samples). While the extent of immune infiltration was similar for CM and UM liver metastases, the ratios of exhausted CD8+ T cells to cytotoxic T cells, to total CD8+ cells and to Th1 cells, were significantly higher in UM [40]. More comprehensive genomic studies strictly on metastatic specimens are needed, as it may help lead to a better understanding of differences in disease course and treatment responses.

In this review we will focus on the current understanding of the molecular and cytogenetic mutations in uveal melanoma (largely based on primary UM), and how this information can provide valuable insight into a patient's prognosis, surveillance, and treatment options. We will also discuss the potential role of liquid biopsies in UM.

\section{Genetic Landscape}

\subsection{Chrosome Copy Number Aberrations}

Primary UM are characterized by recurrent chromosome aberrations in chromosomes $1,3,6,8,9$, and 16 . These cytogenetic alterations are tightly linked to prognosis, and are used for stratification of patients into risk categories. In primary UM, the most common chromosomal aberrations are 1p loss (28-34\%), 1q gain (24\%), 3 loss (50-61\%), 6p gain (28-54\%), 6q gain (28-54\%), 6q loss (35-37\%), 8p loss (17-28\%), 8q gain (36-63\%), 9p loss (24\%), and 16q loss (16\%) [41-43]. In particular, monosomy 3 and gain of chromosome $8 \mathrm{q}$ correlate with increased metastatic risk, with increasing percentages of monosomy 3 and gain of $8 q$ in tumor cells showing a correlation with worse prognosis [44]. 8p loss has also been associated with a more rapid onset of metastasis, indicative of metastatic efficiency [35]. On the contrary, chromosome 6p gain correlated with a good prognosis, suggesting this aberration could have a functionally protective effect [45]. It may also be that $6 \mathrm{p}$ gain portends a better prognosis simply because it is mutually exclusive with monosomy 3 [35]. Monosomy 3 appears to be an early event, while loss of $1 p, 8 p$, and gain of $8 \mathrm{q}$ as secondary events in UM development, relating to large tumor size [42,43].

Of note, chromosome 3 loss uncovers recessive BRCA 1-associated protein (BAP1) mutations, which is located on chromosome 3p21.1 [46]. BAP1 encodes a deubiquinating enzyme (nuclear ubiquitin carboxy-terminal hydrolase) and is a known tumor suppressor gene. Inactivation of $B A P 1$ has been observed in $47 \%$ of primary $\mathrm{UM}$ and $91 \%$ of metastatic $\mathrm{UM}$, correlating with the understanding that loss of BAP1 is a key event to metastasis $[36,47]$. Deletion of chromosome 3 also usually accompanies the development of the class 2 gene 
expression signature, suggesting that one or more genes on chromosome 3 may regulate the emergence of a cancer stem-like phenotype [46]. The 3-year relapse free survival rate for monosomy 3 tumors is $50 \%$ [ 48 ].

The $M B D 4$ gene encodes a DNA glycosylate and is another tumor suppressor gene located on chromosome 3 [49]. Germline MBD4 mutations have been found to predispose to UM (9.15-fold increase in comparison to the general population), and have also been rarely reported in gastrointestinal malignancies, central nervous system malignancies, and acute myeloid leukemia [49,50]. The prevalence of MBD4 germline mutations in UM is approximately $0.23-0.7 \%$ [34,49].

Although MUM tumors typically have a low response rate to immunotherapy, there have been two case reports of success with immunotherapy with germline MBD4 mutated tumors [32,50]. MBD4 mutations result in a $\mathrm{CpG}>\mathrm{TpG}$ hypermutator phenotype with a high tumor mutation burden, which may explain the immunotherapy responsiveness [31,49]. Clinical trials using immunotherapy in MUM patients may want to consider stratifying for MBD4 mutations given the high tumor mutation burden of these tumors and likelihood of response to immune checkpoint inhibitors.

\subsection{Gene Expression Profiling (GEP)}

Aside from cytogenetic status as a way to classify tumors, primary UM is often also classified by gene expression profiling, which relies on a comparison of relative levels of RNA from a 15-gene panel. The commercially available Castle Biosciences DecisionDx-UM Gene Expression Profile classifies tumors into Class 1A and 1B which are low risk, and Class 2 which are high risk of metastasis [51]. The assay comprises 12 discriminating genes (CDH1, ECM1, EIF1B, FXR1, HTR2B, ID2, LMCD1, LTA4H, MTUS1, RAB31, ROBO1, and $S A T B 1)$ and 3 control genes (MRPS21, RBM23, and SAP130) performed on a microfluidics platform [52]. Class $1 \mathrm{~A}$ tumors are classified as "very low risk," with a $2 \%$ risk of metastasis within 5 years. Class $1 \mathrm{~B}$ tumors are classified as "low risk," with a $21 \%$ risk of metastasis within 5 years. Class 2 tumors are classified as "high risk," with a $72 \%$ risk of metastasis within 5 years. Prognostic validation was performed through a prospective study by the Collaborative Ocular Oncology Group [53]. The authors noted the assay may be superior to chromosome 3 status for clinical prognostic testing [53]. More recently, the 5-year outcome results of a prospective study of 89 patients enrolled at four centers showed 5-year Class 1 and 2 metastasis rates to be $10 \%$ and $58 \%$, respectively. Metastasis-free survival rates for Class 1 and 2 tumors were $90 \%$ and $41 \%$, respectively [54].

The GEP of Class 1 tumors closely resemble normal uveal melanocytes and low-grade uveal melanocytic tumors, while the GEP of Class 2 tumors on the other hand resemble the transcriptome of primitive neural/ectodermal cells [55,56]. Class 1 tumors have been shown to harbor mutations in the translation elongation factor EIF1AX and the splicing factor $S F 3 B 1$, whereas mutations in the tumor suppressor gene $B A P 1$ are strongly associated with Class 2 tumors [57]. There is a significant association between class 1 and disomy 3 , and between class 2 and monosomy 3; however, the GEP and chromosome 3 results were discordant in $20.8 \%$ of cases [53].

More recently the messenger-RNA expression of cancer-testis antigen PRAME (Preferentially Expressed Antigen in Melanoma) is being tested along with GEP. The expression of PRAME is believed to represent an independent biomarker providing an additional layer of prognostic precision to the Class 1/Class 2 GEP system [57].

\subsection{Somatic Mutations}

\subsubsection{GNAQ and GNA11}

Mutually exclusive somatic mutations in the G-protein pathway-associated GNAQ and/or GNA11 (92.5\%), CYSTLR2 (4\%), or PLCB4 (2.5\%) genes are found in uveal melanoma [27]. In primary UM GNAQ and GNA11 mutations occur in $50 \%$ and $45 \%$, respectively [28]. Mutations in GNAQ primarily affect either the amino acid Q209P/L (90\%), R183Q (5\%), or G48*/V (5\%). Similarly, mutations in GNA11 primarily affect either the amino acid 
Q209L (94\%), R183C (3\%) or R166H (3\%) [28,58]. These mutations lead to the constitutive activation of the $\mathrm{G} \alpha \mathrm{q}$ and $\mathrm{G} \alpha 11$ subunits by abrogating their intrinsic GTPase activity required to return them to an inactive state, which results in the constitutive activation of G-protein coupled signaling pathways such as MAPK, PI3K, PKC, Akt/mTOR, Rac/Rho, Wnt/ $\beta$-catenin, and Hippo [58-62]. GNAQ/11 mutations are also found in benign uveal nevi, rarely in cutaneous or conjunctival melanoma [59]. They are seen in most UM regardless of cytogenetic status, GEP class, or BAP1 status [63,64]. GNAQ/11 mutations are felt to occur early in UM as tumor-initiating mutations (precursor events) [35]. A 'second hit' event then leads to malignant transformation. GNAQ/11 mutations do not appear to be prognostic $[35,59,63]$. Limited data suggests no statistically different survival between GNAQ and GNA11 and the type and location of mutations, although there may be a trend toward increased survival among patients with a mutation in Q209P, compared to Q209L mutation $[58,65,66]$.

\subsubsection{EIF1AX, SF3B1, SRSF2, and BAP1}

Mutually exclusive mutations in EIF1AX (13\%), SF3B1 (23\%), SRSF2 (4\%), and BAP1 $(33 \%)$ are the second oncogenic event of UM and are associated with markedly distinct prognoses [28]. Tumors with mutations in EIF1AX all have disomy of chromosome 3 and appear to have the lowest risk of metastasis $[27,62,67,68]$. SF3B1 and SRSF2 mutations also mostly have disomy of chromosome $3(88 \%)$ and develop metastases late (median 8.2 years after initial diagnosis) [28,62,68,69]. BAP1 mutations are all associated with monosomy 3 and early metastatic risk [28].

The EIF1AX gene encodes for the eukaryotic translation initiation factor $1 \mathrm{~A}$, an $\mathrm{x}$-linked protein that plays a role in the initiation of translation of mRNA to protein through the recruitment of the ternary complex and assembling of the $43 \mathrm{~S}$ preinitiation complex (PIC) [62] EIF1AX mutations are also found in papillary thyroid carcinomas and ovarian carcinomas, with co-occurrences and cooperation with $R A S$ mutations [27,62,70,71]. Coexpression of mutant NRAS and EIF1AX proteins in low-grade ovarian carcinoma cells promoted proliferation and clonogenic survival [70]. Similarly, cooperation of $R A S$ and EIF1AX mutations were demonstrated in papillary thyroid cell lines and mouse models [71].

The splicing factor gene mutations SF3B1 (splicing factor B3 subunit 1) and SRSF2 (Serine And Arginine Rich Splicing Factor 2) affect proteins involved in $3^{\prime}$ splice site recognition [62]. SRSF2 specifically encodes serine/arginine-rich proteins that bind exonic splicing enhancers, resulting in misregulated exon inclusions that causes an aberrant splicing pattern of many genes including the tumor suppressor genes $A R M C 10$ and EZH2. SRSF2 mutations are also commonly found in chronic myelomonocytic leukemia (47\%) and myelodysplastic syndrome (15\%) [62]. SF3B1 is involved in the recognition of the branch point sequence by encoding the U2 small nuclear riboprotein complex (U2-snRNP) [62]. SF3B1 mutations result in an aberrant splicing pattern of important apoptotic genes such as MCL1 and BCL2/xL through the usage of an alternative $3^{\prime}$ splice site upstream the canonical $3^{\prime}$ splice site [62]. SF3B1 mutations are found in hematologic malignancies such as myelodysplastic syndrome (MDS), myeloproliferative neoplasms, chronic myeloid leukemia, and acute myeloid leukemia (AML), as well as solid tumors such as uveal melanoma, mucosal melanoma, leptomeningeal melanoma, blue nevus-like cutaneous melanoma, neuroblastomas that arise following chromothripsis, estrogen receptor-positive breast cancer, pancreatic ductal adenocarcinoma, prostate cancer, and prolactinoma [72].

$B A P 1$, or BRCA1-associated protein 1, encodes a nuclear deubiquinating enzyme called ubiquitin carboxy-terminal hydrolase (UCH) [46]. In addition to the UCH catalytic domain, BAP1 contains a UCH37-like domain, binding domains for BRCA1 and BARD1, and a binding domain for HCFC1. BAP1 forms a tumor suppressor heterodimeric complex with BRCA1 and BARD1 that is involved in cell proliferation, DNA damage response, and differentiation processes through influencing chromatin remodeling [46,73]. The binding of BAP1 with HCFC1 interacts with histone-modifying complexes [46]. BAP1 also forms 
the Polycomb group repressive deubiquitinase complex with ASXL1 which is involved in stem cell pluripotency and other developmental processes [46].

Most BAP1 mutations in UM are somatic, with only $1-2 \%$ with germline BAP1 mutations [74-77]. Germline mutations in BAP1 are inherited in an autosomal dominant pattern, with the inheritance of a non-functional $B A P 1$ allele with the remaining allele inactivated later in life (two-hit hypothesis) [78]. BAP1 mutation penetrance is relatively high, with one type of cancer developing in more than $80 \%$ of gene carriers [79]. BAP1 tumor predisposition syndrome is associated with $\mathrm{UM}$, malignant mesothelioma, cutaneous melanoma, renal cell carcinoma, basal cell carcinoma, hepatocellular carcinoma, cholangiocarcinoma, and meningioma [80]. The point prevalence of uveal melanoma development in germline $B A P 1$ patients is reported to be about $2.8 \%$ at a median age of 50.5 years [81]. When BAP1 carriers develop UM, the tumor tends to be larger in diameter, involve the ciliary body, and develop at a younger age when compared to non-BAP1 carriers [75]. There is no consensus on surveillance recommendations for patients with germline $B A P 1$, but several groups have recommended a multidisciplinary approach beginning at a young, pre-adolescent age and 5 years before the first reported age at diagnosis of the malignancy associated with germline BAP1 [79,82-85]. Ophthalmological and dermatologic exams should be performed routinely. Malignant mesothelioma and renal cell carcinoma screening recommendations are variable, but involve physical examination and imaging (CT, MRI, ultrasound).

Whether germline $B A P 1$ results in increased risk of metastasis and poorer outcome in comparison to somatic $B A P 1$ or mutation-negative tumors is unclear. Germline $B A P 1$ mutation appeared to result in more metastatic disease compared to non-BAP1 carriers $(71.4 \%$ vs. $18.0 \%)$ in a small comparison between 7 germline BAP1 UM and $455 \mathrm{UM}$ without germline BAP1 [75]. In another small study, germline BAP1 was detected in 4 of 50 metastatic UM cases and 0 of 50 nonmetastatic UM cases ( $8 \%$ vs. $0 \%, p=0.059)$, implying a small but significant increase in metastatic risk [86]. However, a larger cohort of UM tumors carrying somatic BAP1 mutations $(n=43)$, germline BAP1 mutations $(n=11)$, and no mutations $(n=88)$, showed an increased frequency of metastasis in somatic but not germline when compared to mutation-negative [87]. Similarly, DNA extracted from $142 \mathrm{UM}$ tumors showed somatic BAP1 portended a shorter time to metastasis and poorer metastatic outcome compared to germline or mutation-negative tumors; this was not seen between germline and mutation-negative tumors [87]. Rare genetic syndromes such as $B A P 1$ tumor predisposition syndrome are at risk of ascertainment bias, where unaffected carriers or carriers with unusual clinical presentation are less likely to be captured. This may explain the differences in metastatic potential in the studies [88]. The small number of germline tumors in the studies due to the rarity of germline $B A P 1$ is also a limitation. At this time it is unclear as to how germline BAP1 patients with UM should be monitored.

\section{Surveillance}

Clinical factors predictive of metastasis have been evaluated in several large retrospective reviews [89-91]. Increased metastatic risk was correlated with older patient age, ciliary body location, increasing tumor diameter, increasing tumor thickness, darkly pigmented tumor, and the presence of subretinal fluid, intraocular hemorrhage, or extraocular extension [89]. There was also a 2-fold increase in risk for metastasis and death with each increasing tumor size category in the American Joint Committee on Cancer 7th edition [90]. Epithelioid cell type, higher values of mean diameter of ten largest nucleoli, higher microvascular density, extravascular matrix patterns, high mitotic activity, tumor-infiltrating lymphocytes, tumor-infiltrating macrophages, higher expression of insulin-like growth factor-1 receptor, higher expression of human leukocyte antigen Class I and II, MET and PRAME expression are histopathologic features suggestive of poor prognosis [57,91,92]. Additionally, based on the prognostic significance of chromosome copy number aberrations, gene expression profiling, and somatic mutations in primary UM tumors, recommendations for surveillance can be tailored to a patient. 
Currently, the NCCN guidelines divide primary UM patients into three risk categories [93]. Patients are considered low risk if their primary UM is GEP class $1 \mathrm{~A}$, has disomy of chromosomes 3 or gain of chromosome $6 \mathrm{p}$, harbors a EIF1AX mutation, or is $\mathrm{T} 1$ based on AJCC guidelines. Patients are considered medium risk if their tumor is GEP class 1B, T2 or T3 based on AJCC guidelines, or harbors a SF3B1 mutation. Finally, patients are considered high risk if their tumor is GEP class 2, has monosomy 3 or gain of chromosome 8q, harbors a BAP1 mutation, has PRAME expression, or is T4 based on AJCC guidelines. Risk stratification to determine the frequency of follow-up should be based on the highest risk factor present [93].

Based on these three risk categories, the NCCN guidelines recommends surveillance imaging every 12 months for low risk, every 6 to 12 months for 10 years for medium risk, and every 3 to 6 months for 5 years then every 6 to 12 months for 5 more years for high risk patients [93]. Recommended surveillance imaging of the liver includes contrastenhanced MR or ultrasound, with modality preference determined by expertise at the treating institution. Additionally, contrast-enhanced CT of the chest, abdomen, and pelvis or dual energy subtraction chest x-ray may also be performed. The NCCN guidelines recognize that some patients may elect to forgo surveillance imaging after discussions with their treating physicians, as there are limited options for systemic recurrence, and that regular imaging may cause patient anxiety [93].

We take a stronger stance than the NCCN guidelines and highly recommend patients undergo molecular and cytogenetic testing for risk stratification, and as we later discuss, for treatment consideration. We also strongly recommend patients pursue surveillance imaging with MRI of the abdomen and chest imaging (CT or x-ray) based on risk instead of watchful waiting. MRI of the abdomen detects small live metastases missed on PET, avoids the cumulative radiation risk of whole-body CT and PET, and obtained every six months has been shown to detect the metastases before the onset of symptom in $92 \%$ of cases [94-96]. Identifying metastatic disease earlier may provide more treatment options for patients, as advanced stages can cause symptoms and result in life-threatening liver failure. Improved response rates and survival outcomes have been seen when the tumor burden is lower at the initiation of liver-directed therapies including liver resection [97-103]. Although we agree that treatment options for metastatic disease are limited, there have been recent advancements in the field with liver-directed therapy, immunotherapy, and newer therapies such as IMCgp100 [13,14,23,104]. Finally, optimizing surveillance recommendations based on individual metastatic risk has the potential to reduce the burden for low-risk patients, through lower healthcare cost, anxiety, and reduced radiation exposure as seen in other cancers [105-107].

Several studies have shown that physicians utilizing cytogenetic and molecular testing for their UM patients are following surveillance plan recommendations aligned with metastatic risk [54,108-111]. A multicenter prospective study of $138 \mathrm{UM}$ patients who were tested with the commercially available Castle Biosciences DecisionDx-UM Gene Expression Profile found that Class 2 patients had significantly higher surveillance intensity [110]. Not unexpectedly, medical oncology referrals were also more common for high-risk Class 2 patients, likely for consideration of adjuvant clinical trials [110].

Patients also appear to prefer receiving prognostic information even when there are no prophylactic measures that might improve prognosis. A study of $99 \mathrm{UM}$ patients found that the majority (97\%) wanted prognostic information despite being informed that the result would not influence medical care [112]. There were no significant differences between quality of life and depressive symptoms in psychological and physical domains among the groups (monosomy 3, disomy 3, inconclusive). Nearly all patients felt counseling should be offered when receiving the prognostic information. Patients reported wanting to plan for the future as their motivation for having a prognostic test [112]. Similarly, another study of 298 UM patients found that patients want prognostic information as it helped to plan for the future [113]. They also felt they gained a sense of control and hopefulness that continuing medical research and surveillance would prolong their survival, and knowing 
prognostic information reduced their uncertainty and its accompanying anxiety. None of the patients interviewed in detail expressed any regret about having the prognostic test and there was no evidence of harm [113].

\section{Adjuvant Therapy}

Identification of high-risk patients by molecular or cytogenetic testing can also be important for adjuvant therapy consideration. In the past dacarbazine (DTIC), methanolextraction residue of bacilli Calmette-Guérin, low-dose interferon-alpha, and fotemustine were tested as adjuvant therapy without improvement in survival [47]. At this time there are no adjuvant therapies approved for $\mathrm{UM}$, but there are several trials ongoing for highrisk patients that are promising (Table 1). In particular, there are trials targeting c-Met and c-Kit, which are tyrosine-kinase receptors that activate the RAS/ERK and PI3-kinase pathways [47].

Table 1. Ongoing Adjuvant Therapy Trials.

\begin{tabular}{cccc}
\hline Trial Drug(s) and Mechanism of Action & Phase & Identifier & Status \\
\hline Sunitinib (KIT inhibitor) + Valproic Acid (HDAC inhibitor) & II & NCT02068586 & Recruiting \\
\hline Crizotinib (MET inhibitor) & II & NCT02223819 & Active, Not recruiting \\
\hline $\begin{array}{c}\text { Dendritic cell vaccination (immunotherapy) } \\
\text { inhibitor) or Relatlimab (LAG3 inhibitor) }\end{array}$ & III & NCT01983748 & Recruiting \\
\hline Ipilimumab (CTLA4 inhibitor) + Nivolumab (PD1 inhibitor) & II & NCT02519322 & Active, Not recruiting \\
\hline
\end{tabular}

Sunitinib targets VEGF/PDGFR along with C117 (c-Kit), which is vastly expressed in MUM [114]. Sunitinib showed some response in the metastatic setting and is now being studied in the adjuvant setting for high-risk UM patients. In a pilot study of 20 MUM patients, 17 of whom failed previous treatments, one PR and 12 SD was seen with a median PFS and OS of 4.2 and 8.2 months, respectively [114]. The degree of c-Kit expression in MUM cells was not associated with longer PFS or OS [114]. In the adjuvant setting, a retrospective analysis of sunitinib given for 6 months to high-risk UM patients demonstrated longer OS compared to historical controls (HR 0.53, $p=0.041$ ) [115]. Adjuvant sunitinib was then compared to 6 months of valproic acid (histone deacetylase inhibitor) in a randomized phase II study, and the 2-year OS rate and 18-month RFS rate were similar between the groups [116]. Currently, there is an actively recruiting randomized phase II trial comparing adjuvant sunitinib with valproic acid for 12 months compared to surveillance in high-risk patients (NCT02068586).

Crizotinib is a selective small-molecule inhibitor against c-Met, anaplastic lymphoma kinase, and ROS1 [117]. In a UM metastatic mouse model, crizotinib was found to significantly decrease distant metastases compared to untreated controls [117]. A phase II trial of 48 weeks of adjuvant crizotinib in high-risk UM is ongoing (NCT02223819). As of $01 / 31 / 2020$ the median RFS was 30.6 months and median OS was not reached for 34 patients [118].

Adjuvant dendritic cell vaccination is also being studied in UM. A phase II trial of adjuvant $D C$ vaccination in patients with high-risk cytogenetic characteristics was conducted in the Netherlands. Due to the low accrual rates, the trial was stopped prematurely, but of the 23 patients that received at least 1 cycle, median disease-free survival was 34.5 months with a median OS of 51.8 months [119]. A randomized open-label phase III study of adjuvant vaccination with tumor RNA-loaded autologous DCs in patients with resected monosomy 3 UM is open in Germany (NCT01983748).

Finally, there are several adjuvant immunotherapy trials currently ongoing. There is a phase II single-arm multicenter study of adjuvant ipilimumab combined with nivolumab for high-risk UM patients (NCT03528408). There is also a randomized phase II trial of neoadjuvant and adjuvant nivolumab with or without ipilimumab or relatlimab (anti-LAG-3) 
in melanoma that is including any risk stage IIIB to stage IV uveal melanoma patients (NCT02519322). Adjuvant ipilimumab alone in 10 high-risk UM patients demonstrated $80 \%$ distant disease free survival at 36 months in a phase I/II trial [120].

\section{Treatment Based on Mutational Profile}

\subsection{GNAQ and GNA11}

Direct targeting of GNAQ and GNA11 may be difficult as these mutations abrogate the intrinsic GTPase activity that would normally allow these proteins to return to their GDPbound inactive state. The focus, instead, has been to target downstream signaling molecules that are activated by GNAQ/11 mutations such as the RAF/MEK/ERK, PLC i Á/PKC, $\mathrm{PI} 3 \mathrm{~K} / \mathrm{AKT} / \mathrm{mTOR}$, and Trio/Rho/Rac/YAP1 pathways (Figure 2) [121]. Unfortunately, the results of therapies targeting these pathways have overall been disappointing. Recent reviews by Croce et al. and Mallone et al. summarize the most recent studies of targeted therapies in UM $[47,121]$. Ongoing targeted therapy trials for MUM are listed in Table 2.

YM-254890 and FR900359 are two G $\alpha$ q/11 inhibitors that show promise in vitro, but have not been evaluated for clinical application. YM-254890, a bacterial cyclic depsipeptide, prevents GDP release and selectively inhibits G $\alpha$ q activation [122]. FR900359 is a plant-based cyclic depsipeptide that acts similarly to YM-254890, selectively inhibiting $\mathrm{G} \alpha \mathrm{q} / 11 / 14$ resulting in cell-cycle arrest and induction of apoptosis [123-125]. FR900359 also inhibits ERK1/2 activation, migration and reinstated melanocytic differentiation [123].

ARF6, a small GTPase and ADP-ribosylation factor 6, may be another potentially actionable target for $\mathrm{UM}$, as it is required for oncogenic $\mathrm{G} \alpha \mathrm{q}$ signaling and $\beta$-catenin signaling [121]. ARF6 facilitates membrane vesicle trafficking of $G \alpha Q$ as well as trafficking of $\beta$-catenin to the nucleus, resulting in activation of transcription factors that promote invasion and metastasis [121]. NAV-2729 is an ARF6-specific small molecule inhibitor that has shown the reduction of UM cell proliferation in vitro and in orthotopic xenografts [126].

As GNA1Q/11 mutations lead to the constitutive activation of the mitogen-activated protein kinase (MAPK) pathway, downstream effectors have been investigated as targets. Unfortunately, thus far no inhibitor has been successful in UM. A phase II study of an ERK1/2 inhibitor (ulixertinib, BVD-523) failed to demonstrate activity in patients with MUM [127]. There was a systematic review of three open-label phase II, two open-label phase I, and one placebo-controlled phase III trial of different MEK inhibitors in MUM showing a disappointing median PFS of 3.1 weeks to 16 weeks and an overall response rate of 0 to $14 \%$ [128]. Despite encouraging results of a phase II study of selumetinib compared with investigator-choice chemotherapy, the phase III study of selumetinib in combination with DTIC (SUMIT trial) failed to show a clinical benefit [129-131]. Other trials included in the review were for trametinib monotherapy [132,133], trametinib with uprosertib (AKT inhibitor) [132], and binimetinib with sotrastaurin (PKC inhibitor) (NCT01801358). Mergener et al. demonstrated that BAP1 mutations and monosomy 3 were associated with higher resistance to MEK inhibition [73]. Their analysis suggested that these tumors with $B A P 1$ mutation are more resistant to MEK inhibitors because downregulation of eukaryotic translation initiation factor 2A (EIF2A) seen in BAP1 mutated tumors may lead to a decrease in ribosome biogenesis while inducing an adaptive response to stress [73].

There is still active interest in pursuing MEK inhibitors in combination with other therapies for the treatment of MUM. The randomized phase II study of selumetinib alone or in combination with paclitaxel was recently completed (SelPac, ISRCTN29621851). Selumetinib has been shown to enhance paclitaxel-induced tumor apoptosis in preclinical models [134]. The primary analysis presented at ESMO 2019 showed a slight statistical improvement in median PFS but not OS. Median PFS and OS in the combination arm was 4.8 months and 9 months, compared with the monotherapy arm of 3.4 months and 10 months [135]. ORR was $14 \%$ in the combination and $4 \%$ in the monotherapy arm [135]. The phase IB open label trial of intermittent selumetinib dosing in UM is still recruiting (NCT02768766). Intermittent dosing of selumetinib hopes to test a higher drug dose for more effective blockage of the MAPK pathway, prevent resistance development, and 
achieve a better toxicity profile. Treatment-related adverse events such as diarrhea and acne-like skin rash were observed in $97 \%$ of patients treated with selumetinib in the previous phase II study [130]. Finally, UM patient-derived xenograft models suggest combining selumetinib with an ERK inhibitor or mTORC1/2 inhibitor may be an effective combination [136].

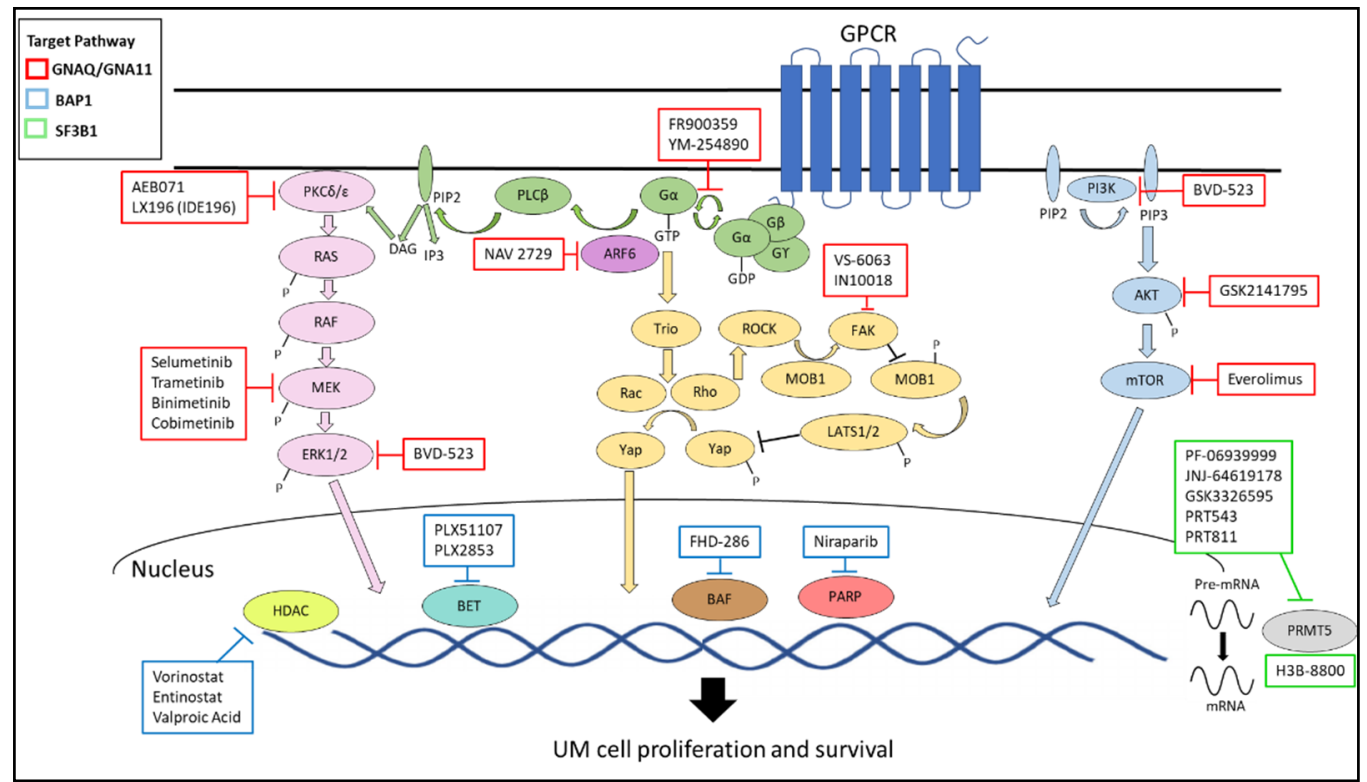

Figure 2. Signaling Pathways in UM. Adapted from “Targeted Therapy of Uveal Melanoma: Recent Failures and New Perspectives" by Michela Croce et al. 846 [121].

Table 2. Ongoing Targeted Therapy Trials for MUM.

\begin{tabular}{|c|c|c|c|}
\hline Trial Drug(s) and Mechanism of Action & Phase & Identifier & Status \\
\hline BVD-523 (ERK1/2 inhibitor) & II & NCT03417739 & Active, Not recruiting \\
\hline Intermittent Selumetinib (MEK inhibitor) & IB & NCT02768766 & Recruiting \\
\hline LXS196 (PKC inhibitor) +/ - HDM201 (MDM2 inhibitor) & I & NCT02601378 & Active, Not recruiting \\
\hline $\begin{array}{c}\text { IDE196 (PKC inhibitor) + / - Binimetinib (MEK inhibitor) or } \\
\text { Crizotinib (MET inhibitor) }\end{array}$ & $\mathrm{I} / \mathrm{II}$ & NCT03947385 & Recruiting \\
\hline AEB071 (PKC inhibitor) + BYL719 (PI3K- $\alpha$ inhibitor) & I & NCT02273219 & Active, Not recruiting \\
\hline Defactinib (FAK inhibitor) + VS-6766 (RAF/MEK inhibitor) & II & NCT04720417 & Recruiting \\
\hline IN10018 (FAK inhibitor) +/ - Cobimetinib (MEK inhibitor) & IB & NCT04109456 & Recruiting \\
\hline $\begin{array}{c}\text { Cabozantinib (multi-kinase inhibitor) vs. Dacarbazine (alkylating } \\
\text { agent) or Temozolomide (alkylating agent) }\end{array}$ & II & NCT01835145 & Active, Not recruiting \\
\hline H3B-8800 (SF3B complex modulator) & I & NCT02841540 & Recruiting \\
\hline PF-06939999 (PRMT5 inhibitor) & I & NCT03854227 & Recruiting \\
\hline JNJ-64619178 (PRMT5 inhibitor) & I & NCT03573310 & Active, Not recruiting \\
\hline GSK3326595 (PRMT5 inhibitor) +/ - Pembrolizumab (PD1 inhibitor) & I & NCT02783300 & Recruiting \\
\hline PRT543 (PRMT5 inhibitor) & I & NCT03886831 & Recruiting \\
\hline PRT811 (PRMT5 inhibitor) & I & NCT04089449 & Recruiting \\
\hline Vorinostat (HDAC inhibitor) & II & NCT01587352 & Recruiting \\
\hline Entinostat (HDAC inhibitor) + Pembrolizumab (PD1 inhibitor) & II & NCT02697630 & Active, Not recruiting \\
\hline PLX2853 (BET inhibitor) & IB/IIA & NCT03297424 & Recruiting \\
\hline FHD-286 (BAF inhibitor) & I & NCT04879017 & Recruiting \\
\hline Niraparib (PARP inhibitor) & II & NCT03207347 & Recruiting \\
\hline
\end{tabular}


PKC inhibitors are also being investigated as monotherapy or in combination in MUM. GNAQ/11 mutations result in activation of PLC $\beta$ which produces diacylglycerol and triggers the activation of the PKC pathway. The pan-PKC inhibitor sotrastaurin (AEB071) as monotherapy showed 1 partial response (PR), 47\% disease stabilization (SD), and a PFS of 15.4 weeks [137]. The phase I clinical trial evaluating LXS196, a new generation PKC inhibitor, alone or in combination with HDM201 (MDM2 inhibitor) in MUM is active, but no longer recruiting (NCT02601378). Among the 66 evaluable patients treated with LXS196 monotherapy, 6 had a PR and 45 had SD as their best response, suggesting promising clinical activity for LXS196 as a single agent with manageable toxicity profile [138]. In 2018 Novartis entered into an exclusive license agreement with IDEAYA Biosciences to develop and commercialize LXS196, and the compound was recorded as IDE196 for future development. IDE196 (darovasertib) is currently being tested as monotherapy and in combination with either binimetinib (MEK inhibitor) or crizotinib (MET inhibitor) in an ongoing phase I/II clinical trial of solid tumors harboring a GNAQ/GNA11 mutation (NCT03947385). Based on a preliminary analysis, darovasertib monotherapy resulted in a 57\% 1-year overall survival and 13.2 month median OS in a predominantly 2 nd and 3rd line therapy MUM patient population [139]. The combination of darovasertib and binimetinib resulted in tumor reduction in $79 \%$ of evaluable MUM patients, with 2 partial responses out of the 9 patients with more than 2 post-baseline scans. In the darovasertib and crizotinib group 1 of 2 evaluable patients had a partial response. IDE196 was found to have synergistic anti-tumor effects when combined with CGM097 (p53-MDM2 inhibitor) or RAD001 (mTORC1 inhibitor) in UM PDX screening studies, suggesting other new potential combination therapies for IDE196 in MUM [140].

Oncogenic $\mathrm{G} \alpha$ signaling also results in constitutive activation of the PI3K/AKT/mTOR pathway. A small 13 patient phase II trial of the mTOR inhibitor everolimus combined with somatostatin receptor agonist pasireotide had limited clinical benefit [141]. Preclinical studies suggested PI3K inhibitors had limited effects as monotherapy, but they had synergistic effects against tumor growth when combined with a MEK inhibitor or PKC inhibitor [142,143]. The PKC inhibitor AEB071 and the PI3K- $\alpha$ inhibitor BYL719 drug combination is currently being tested in a clinical phase I study (NCT02273219). The potent synergy between everolimus (mTOR inhibitor) and the PI3K inhibitor GDC0941 was demonstrated in drug combination screening of UM cell lines, which may be another possible combination for MUM [144].

The multi-kinase inhibitor sorafenib, which targets the RAF/MEK/ERK pathway and VEGFR/PDGFR, resulted in limited overall efficacy in a phase II study by the Southwest Oncology Group (SWOG) cooperative group when combined with carboplatin and paclitaxel [145]. In a different phase II study, first-line sorafenib was compared to placebo in MUM patients (STREAM); improvement in median PFS was seen (5.5 months vs. 1.9 months) but there was no OS benefit [146]. Another multi-kinase inhibitor cabozantinib was compared against dacarbazine or temozolomide and no improvement in PFS was seen (NCT01835145) [147].

Finally, studies targeting the Hippo/YAP pathway are underway. The non-canonical G $\alpha$ q signaling pathway activates a highly conserved Rho-GEF, TRIO, and the consequent stimulation of Rho-regulated pathways leading to the activation of YAP, independently of PLC- $\beta$ [148]. The tyrosine kinase FAK provides a direct link between G $\alpha q$ and tyrosine phosphorylation networks controlling YAP and has been shown to promote UM growth [149]. FAK is associated with drug resistance as it can be activated in cancer cells when it is exposed to other tyrosine kinase inhibitors. FAK can also be activated by cellular stress and signal through critical nodes in signal transduction pathways such as MEK [150]. It has been shown that targeting FAK kinase activity has the potential to modulate intra- tumoral regulatory T cells (Treg) levels establishing an immunosuppressive tumor microenvironment [151]. Interestingly, UM represents human cancer harboring the highest level of FAK overexpression [149]. Furthermore, PTK2 expression (the gene that encodes for FAK) has been significantly correlated with reduced overall survival in UM 
patients, aligning with its potential biological role in UM [150]. UM cell lines demonstrated dose-dependent sensitivity to FAK inhibition by the two FAK inhibitors PF562771 and VS-4718 [149]. VS-4718 treated mice also experienced reduction in UM tumor size [149]. Kinome-wide CRISPR-Cas9 sgRNA screen to identify synthetic lethal gene interactions revealed that FAK and MEK-ERK co-targeting has remarkable synergistic growth-inhibitory effects in UM cells and exerted cytotoxic effects leading to tumor regression in UM xenograft and liver MUM models in vivo [152]. Both the phase II trial of defactinib (VS-6063, FAK inhibitor) and VS-6766 (dual RAF/MEK inhibitor) (NCT04720417) and the phase Ib trial of IN10018 (FAK inhibitor) alone and in combination with cobimetinib (MEK inhibitor) (NCT04109456) are actively recruiting.

\subsection{EIF1AX}

EIF1AX mutations have been found to cooperate with $R A S$ mutations to induce tumorigenesis [70,71]. The C-terminal EIF1AX-A113splice mutation drives an ATF4-induced dephosphorylation of EIF2 $\alpha$, resulting in increased protein synthesis. ATF4 also cooperates with c-MYC, which is stabilized by RAS, to sensitize mTOR to amino acid supply. These mutually reinforcing events may result in vulnerabilities to MEK, BRD4, and mTOR kinase inhibitors [71]. Since metastatic UM rarely possesses EIF1AX mutation, EIF1AX has not been a target for the treatment of metastatic UM.

\subsection{SF3B1 and SRSF2}

Since SF3B1 and SRSF2 are involved in splicing, there has been growing interest in splicing modulators. Several bacterial and synthetic splicing inhibitors have been studied as SF3B1 inhibitors, including FR901464, spliceostatin B, spliceostatin E, thailanstatin, meyamycin, sudemycin, pladienolides A-G, E7107, FD-895, herboxidiene, and isogingketin [62]. These inhibitors confer high cytotoxic effects by regulating Mcl-1 splicing and inhibiting cell proliferation in a dose-dependent manner [62]. E7107, a semisynthetic derivative of the natural product pladienolide B, was evaluated in a phase I study in patients with advanced solid tumors [153]. Disappointingly no complete or partial responses were observed during treatment.

SF3B1 mutations may also be sensitive to nonsense-mediated mRNA decay (NMD) inhibitors [154]. SF3B1 mutated chronic lymphocytic leukemia, UM, and pancreatic cell lines treated with an NMD inhibitor resulted in increased expression of SF3B1-associated cryptic transcripts, suggesting a role of NMD in the pathogenic effects of SF3B1 mutations [154].

H3B-8800 may be promising as cells harboring SF3B1 mutations are more sensitive to this inhibitor; in SF3B1 mutant cells preferential inhibition results in alternative $3^{\prime}$ ss enrichment [155]. A phase I, first-in-human study of H3B-8800 in patients with MDS, AML, or chronic myelomonocytic leukemia is ongoing (NCT02841540).

PRMT5 (protein arginine methyltransferase 5) inhibitors are being investigated in SF3B1 and SRSF2 mutant tumors including uveal melanoma. PRMT5 directly methylates arginine residues of several splicing factors which contributes to spliceosome assembly and promotes canonical splicing of many essential genes in cancer cells [156]. PRMT5 inhibitors led to increased survival in mice with leukemias with SRSF2 mutations but not wildtype [157]. Specifically in uveal melanoma, PRMT5 inhibition has been demonstrated to regulate DNA replication and repair pathways [156]. In SF3B1 mutated UM cells, combining PRT543 (PRMT5 inhibitor) with a PARP inhibitor or DNA-alkylating agent yielded a synergistic reduction in cell viability [156]. There are currently five phase 1 open label, dose-escalation studies of PRMT5 inhibitors in advanced solid tumors: PF06939999 (NCT03854227), JNJ-64619178 (NCT03573310), GSK3326595 (NCT02783300), PRT543 (NCT03886831), and PRT811 (NCT04089449).

A recent multicenter retrospective analysis evaluated patients with SF3B1 mutations after immune checkpoint inhibitors [158]. 58 patients with deleterious SF3B1 mutations received immunotherapy: single-agent PD-1 in 15 patients, single-agent CTLA-4 in 4 patients, and dual checkpoint inhibitor in 15 patients. The median time from initial diagnosis 
to metastasis was 6.1 years and $29 \%$ of patients had non-liver metastasis. $27 \%$ had received prior systemic therapy and 35\% had received prior hepatic regional therapy. Median OS and 1-year survival after immunotherapy were numerically superior to historical controls. Median OS for all patients from the time of metastasis was 3.9 years, and 1-year OS from time of metastasis was 94\% [158]. Response rates were comparable to other immunotherapy trials, with 9\% PR and 39\% SD [14,23,159]. Bigot et al. demonstrated that SF3B1 mutations generate shared neoantigens that are uniquely expressed by UM cells, leading to recognition and killing by specific CD8 T cells [160]. This could potentially explain the prolonged survival with immunotherapy and in general for SF3B1 mutated patients. Future clinical trials may need to stratify for SF3B1 mutations given the more indolent course of these tumors [158].

\subsection{BAP1}

Binding of BAP1 to ASXL1 results in the formation of the polycomb complex that deubiquinates histone 2A [161]. BAP1 loss may result in sensitivity to HDAC inhibitors through increased ubiquinated expression. In preclinical UM models HDAC inhibition has been shown to suppress migration and invasion of UM cells, and induce apoptosis, morphologic differentiation, cell cycle arrest, and shift from a high-risk (class 2) to a low-risk (class 1) gene expression profile [162,163]. Many HDAC inhibitors are being studied in UM including valproic acid, panobinostat, vorinostat, tricostatin A, tenovin-6, depsipeptide, MS-275, quisinostat, JSL-1, MC1568, and MCI1575 [62,121,164]. The phase II trial evaluating the HDAC inhibitor vorinostat in MUM patients is recruiting (NCT01587352). As mentioned above, there is an ongoing phase II study of valproic acid with sunitinib in the adjuvant setting for high-risk UM patients (NCT02068586). Six months of adjuvant valproic acid showed a similar 2-year OS rate and 18-month RFS rate as adjuvant sunitinib [116].

The HDAC inhibitor entinostat was combined with the PD-1 inhibitor pembrolizumab in a multicenter, open label phase II study of MUM patients (PEMDAC, NCT02697630) [165]. As of June 21, 2019, the ORR for the 29 enrolled MUM patients was $10 \%$ and median OS was 11.5 months [166]. Grade 3 to 4 adverse events were reported in $62 \%$ of patients.

The combination of neratinib (HER-2 and epidermal growth factor receptor inhibitor) and entinostat (HDAC inhibitor) resulted in additive cytotoxic effects in PDX of UM, through multifactorial killing via mitochondrial dysfunction and toxic autophagy [167]. MEK inhibition with HDAC inhibition may also hold promise, as the combination resulted in a considerable reduction in growth of both subcutaneous and liver metastasis in xenograft models [168].

BAP1 loss also leads to increased histone H3 lysine 27 (H3K27), which in turn, increases the expression of EZH2 [169]. However, EZH2 inhibitors did not inhibit tumor growth of UM cells regardless of their BAP1 status [170].

Bromodomain and extra-terminal (BET) inhibitors have been investigated in UM. The BET family of proteins (BRD2, BRD3, BRD4, BRDT) are chromatin readers that bind to acetylated lysine residues on histone tails [171]. BAP1 has been shown to be bridged to BRD4 by a physical interaction between additional sex combs-like protein 3 (AXL3) [172]. BET inhibitors like JQ1 competitively displace BRD4 from acetylated histones, resulting in suppression of c-Myc and c-Myc dependent target genes. Located on 8q24.1, the oncogene MYC is amplified in nearly $40 \%$ of UM [173]. The BET inhibitor JQ1 had cytotoxic activity in UM cell lines with GNAQ/GNA11 mutations, while in cells without mutations there was little effect [174]. However, when a second-generation BET inhibitor (PLX51107) was tested in different advanced cancers including UM, resistance was seen in UM patients with liver metastases [175]. Combining PLX51107 with AZD4547 (fibroblast growth factor receptor) showed efficacy in UM cells and may be the basis for a novel combination [175]. PLX2853 is another second generation BET inhibitor that is being investigated in advanced malignancies including uveal melanoma (NCT03297424).

The BRG/Brahma-associated factors (BAF) family of chromatin remodeling complexes, also referred to as mSWI/SNF complex, has been found to be a major regulator of 
lineage- and disease-specific transcriptional programs [176]. Copy number deletions have been found in many subunits of the SWI/SNF complex in BAP1 deleted malignant mesothelioma tumors, making BAF inhibitors a potential target in BAP1 mutated tumors [177]. FHT-1015 is a selective inhibitor of SMARCA4 and SMARCA2 (also known as BRG1 and BRM), the ATPase component of the BAF complex [159]. In UM, FHT-1015 resulted in enhancer occupancy reduction of SOX10 and MITF transcription factors, two essential proteins in supporting the proliferation and survival of UM cells. In mouse xenograft models of UM, BAF inhibition was well tolerated and resulted in dose-dependent tumor regression that correlated with pharmacodynamic modulation of BAF-targeted gene expression [159]. A phase I dose escalation and expansion study of FHD-286 in MUM is recruiting (NCT04879017).

Lastly, PARP inhibitors are currently being studied as UM therapy, since BAP1 deficiency results in impaired homologous recombination. BAP1 forms a complex with BRCA1 and BARD1, forming an E3 ubiquitin ligase that regulates the homologous recombination pathway [178]. Due to impaired homologous recombination, tumor cells are more dependent on other DNA repair pathways. In one study, BAP-1 loss was found to sensitize renal cancer cells to the PARP inhibitor Olaparib as well as radiation [179]. Loss of BAP1 in the mouse melanoma cell line B16F10 resulted in increased sensitivity to radiation and rucaparib [180]. A clinical trial of the PARP inhibitor (Niraparib) in BAP1-deficient cancers (UM included) is ongoing (NCT03207347).

\section{Liquid Biopsy}

Genetic and molecular testing of uveal melanoma at this time relies on tissue from enucleation or samples from a fine needle aspiration biopsy (FNAB) of the eye. There is some concern about intratumor genetic heterogeneity and single site sampling resulting in discordance [181]. Liquid biopsy has been gaining popularity in other tumors as a non-invasive alternative approach to analyze molecular features of a tumor. Circulating tumor cells (CTCs), circulating tumor DNA (ctDNA), cell-free microRNA (miRNAs), and tumor-derived extracellular vesicles (EV) are different components that can be analyzed in a liquid biopsy. UM is unique in that it spreads via the blood rather than the lymphatic system, which may lend itself better to a liquid biopsy. Liquid biopsies of the aqueous humor are also under investigation in UM [182]. Liquid biopsies could be a valuable tool for early diagnosis, recurrence, and response to treatment.

Jin and Burnier recently reviewed the current evidence of liquid biopsies in UM [182]. Advances in technology have resulted in significant progress in liquid biopsies in UM. However, the authors concluded that at this time designing a clinically useful liquid biopsybased screening test with high enough specificity and sensitivity remains an obstacle. Below we review the different components of liquid biopsies studied so far in UM.

In 1993, Tobal et al. published the earliest report of CTCs in UM [183]. RNA transcripts of melanoma-associated proteins were measured with RT-PCR, and they were able to detect as few as 10 CTCs in $5 \mathrm{~mL}$ of blood in 3 of $6 \mathrm{UM}$ patients [183]. Since then, different methods of CTC detection have been explored. One method is using CellSearch which is an FDA-approved CTC detection approach [184]. Using immunomagnetic isolation, cells are first enriched for CD146. Then expression of the high-molecular weight melanoma-associated antigen and staining for CD45 and CD34 allows UM CTCs to be differentiated from leukocytes and endothelial cells. In a study by Bande et al., 50\% of primary non-metastatic UM patients had more than 1 CTC detected in their blood sample using CellSearch compared to none in patients with a nevus [185]. In 40 patients with MUM, only $30 \%$ had detectable CTCs using CellSearch; those who had detectable CTCs had worse overall survival [184]. CTC positivity and patient outcome was also negatively correlated in another study with $40 \mathrm{UM}$ patients (20 non-metastatic, 19 metastatic) using CellSearch [186]. Mazzini et al. used a detection method based on size filtration and found CTCs in 17 of 31 UM patients, but none in choroidal nevus patients [187]. Significantly worse disease-free and overall survival was found in patients with more than $10 \mathrm{CTCs}$ per 
$10 \mathrm{~mL}$ blood in this study [187]. Cajello et al. reported detectable CTCs in 29 of their $30 \mathrm{UM}$ patients $(87.5 \%)$ using RT-PCR [188]. CTCs were found in nearly diagnosed, irradiated, enucleated, and observed patients regardless of tumor size and time period following treatment. Of note none of the patients developed metastasis [188]. The CTC detection rates are highly variable across different studies and methods which is problematic [182] Different methods that may improve detection efficiency include arterial sampling and combining two antibodies instead of a single one [189,190].

ctDNA are small fragments of DNA that are released by tumor cells into the blood, likely from apoptosis, necrosis, and active release mechanisms [182]. Bidard et al. used a mutation-specific bidirectional pyrophosphorolysis-activated polymerization (Bi-PAP) technique and found point mutations in GNAQ and GNA11 in the ctDNA of 22 of 26 patients [184]. There was a correlation between ctDNA levels and hepatic miliary metastases, tumor volume, and CTC count. They also found ctDNA to be an independent prognostic factor for PFS and OS. Another studying using the same Bi-PAP technique detected ctDNA in 20 of 21 MUM patients and levels of ctDNA correlated with tumor mass [191]. Metz et al. used an ultradeep amplicon sequencing technique and found GNAQ and GNA11 mutations in ctDNA of 9 of 22 patients, with no correlation to clinical parameters [192]. Jin and Burnier's group used a different technique of digital droplet PCR for ctDNA detection of GNAQ, GNA11, PLCB4, and CYSTLR2 mutations in 40 patients with UM, nevus, and healthy subjects, and found a strong correlation between ctDNA detection and disease [182].

Recently, the ctDNA of 17 MUM patients treated with a PKC inhibitor in a phase 1 clinical trial were analyzed [193]. This study found baseline ctDNA to be strongly correlated with baseline lactate dehydrogenase level and baseline disease burden. ctDNA accurately predicted patients with clinical benefit to PKC inhibitor and detecting disease progression prior to radiological progression [193]. ctDNA use in the phase 2 IMCgp100-102 trial of tebentafusp (IMCgp100) in previously treated MUM patients was also recently presented at the 2021 European Society for Medical Oncology (ESMO) Congress [194]. Reduction of ctDNA by Week 9 while on tebentafusp was strongly associated with OS. $14 \%$ of patients had complete ctDNA clearance and long OS, including some patients with the best response of stable or progressive disease. The majority $(70 \%)$ of evaluable patients had any ctDNA reduction while $5 \%$ of patients had radiographic response per the RECISTv1.1 criteria, suggesting ctDNA may be more sensitive than RECIST [194].

miRNAs are small noncoding RNAs that function as regulators of gene expression that can impact cancer development [182]. Several studies have found circulating miRNAs differentially expressed in UM patients compared to healthy controls [195-200]. The circulating miRNAs differ between the studies, but circulating miR-164a seems to be consistently found in UM patients with further increase upon the development of metastasis [196].

Extracellular vesicles are nanoparticles that are categorized mainly into microvesicles, apoptotic bodies, and exosomes [182]. RNA, DNA, and proteins are transported by EV. Studies on EV in UM are limited. Eldh et al. isolated exosomes from liver perfusate of $12 \mathrm{UM}$ patients with liver metastases and found a higher concentration of exosomes in systemic blood in those patients compared to healthy controls [201]. The exosomes of the UM patients also contained a similar miRNA profile between patients, but dissimilar to other tumor cell lines [201].

\section{Conclusions}

The genetic landscape of uveal melanoma is unique when compared to other tumors. UM tumors have a low tumor mutational burden, but they do have specific recurrent mutations. UM tumors often harbor a tumor-initiating mutation in GNAQ or GNA11 with secondary mutation in EIF1AX, SF3B1, SRSF2, or BAP1 that determines metastatic potential. UM tumors are also characterized by distinct chromosomal abnormalities that are tightly linked to prognosis; in particular, monosomy 3 , gain of $8 \mathrm{q}$, and loss of $8 \mathrm{p}$ are associated with higher metastatic risk. GEP also adds to the prognostication of primary UM tumors, 
all of which aids clinicians and their patients in determining surveillance patterns and the possibility of adjuvant therapy trial enrollment. In addition to prognosis, UM-specific mutations have become valuable targets in a landscape where there are few effective therapies for MUM. Finally, there is some variability in survival outcomes in patients with MUM, which may be explained by differences in molecular and cytogenetic mutations of the tumor; monosomy 3 tumors appear to have worse outcomes and SF3B1 mutated tumors with improved outcomes, but this needs to be elucidated further [16,158,202].

Most of our mutational knowledge is based on primary UM and a better understanding of the genetic landscape in metastatic UM is needed. Liquid biopsies, especially ctDNA, focusing on UM-specific mutations are promising and could become an important biomarker for future clinical use.

In summary, primary tumor biopsies should be performed to obtain genetic information of UM as it provides valuable insight into a patient's prognosis, surveillance, and treatment options.

Author Contributions: Writing—original draft preparation, R.S.S.; writing—review and editing, R.S.S., M.O. and T.S. All authors have read and agreed to the published version of the manuscript.

Funding: This research received no external funding.

Conflicts of Interest: M.O. is a consultant for Immunocore and sits on the Scientific advisory board of Trisalus. R.S.S. and T.S. declare no conflict of interest.

\section{References}

1. Singh, A.D.; Turell, M.E.; Topham, A.K. Uveal melanoma: Trends in incidence, treatment, and survival. Ophthalmology 2011, 118, 1881-1885. [CrossRef] [PubMed]

2. Shields, J.A.; Shields, C.L. Intraocular Tumors: An Atlas and Textbook; Wolters Kluwer Health: Philadelphia, PA, USA, 2016.

3. Aronow, M.E.; Topham, A.K.; Singh, A.D. Uveal Melanoma: 5-Year Update on Incidence, Treatment, and Survival (SEER 1973-2013). Ocul. Oncol. Pathol. 2018, 4, 145-151. [CrossRef]

4. Kujala, E.; Makitie, T.; Kivela, T. Very long-term prognosis of patients with malignant uveal melanoma. Investig. Ophthalmol. Vis. Sci. 2003, 44, 4651-4659. [CrossRef] [PubMed]

5. Diener-West, M.; Reynolds, S.M.; Agugliaro, D.J.; Caldwell, R.; Cumming, K.; Earle, J.D.; Hawkins, B.S.; Hayman, J.A.; Jaiyesimi, I.; Jampol, L.M.; et al. Development of metastatic disease after enrollment in the COMS trials for treatment of choroidal melanoma: Collaborative Ocular Melanoma Study Group Report No. 26. Arch. Ophthalmol. 2005, 123, 1639-1643. [CrossRef] [PubMed]

6. Augsburger, J.J.; Correa, Z.M.; Shaikh, A.H. Effectiveness of treatments for metastatic uveal melanoma. Am. J. Ophthalmol. 2009, 148, 119-127. [CrossRef] [PubMed]

7. Kuk, D.; Shoushtari, A.N.; Barker, C.A.; Panageas, K.S.; Munhoz, R.R.; Momtaz, P.; Ariyan, C.E.; Brady, M.S.; Coit, D.G.; Bogatch, K.; et al. Prognosis of Mucosal, Uveal, Acral, Nonacral Cutaneous, and Unknown Primary Melanoma from the Time of First Metastasis. Oncologist 2016, 21, 848-854. [CrossRef] [PubMed]

8. Yang, J.; Manson, D.K.; Marr, B.P.; Carvajal, R.D. Treatment of uveal melanoma: Where are we now? Ther. Adv. Med. Oncol. 2018, 10, 1758834018757175. [CrossRef] [PubMed]

9. Lane, A.M.; Kim, I.K.; Gragoudas, E.S. Survival Rates in Patients After Treatment for Metastasis from Uveal Melanoma. JAMA Ophthalmol. 2018, 136, 981-986. [CrossRef] [PubMed]

10. Khoja, L.; Atenafu, E.G.; Joshua, A.M.; International Rare Cancer's Intiative-Ocular Melanoma Group. Meta-analysis of phase II trials in metastatic uveal melanoma (MUM) to determine progression-free (PFS) and overall survival (OS) benchmarks for future phase II trials: An irci-ocular melanoma initiative. J. Clin. Oncol. 2016, 34, 9567. [CrossRef]

11. Khoja, L.; Atenafu, E.G.; Suciu, S.; Leyvraz, S.; Sato, T.; Marshall, E.; Keilholz, U.; Zimmer, L.; Patel, S.P.; Piperno-Neumann, S.; et al. Meta-Analysis in Metastatic Uveal Melanoma to Determine Progression-Free and Overall Survival Benchmarks: An International Rare Cancers Initiative (IRCI) Ocular Melanoma study. Ann. Oncol. 2019, 30, 1370-1380. [CrossRef] [PubMed]

12. Jochems, A.; van der Kooij, M.K.; Fiocco, M.; Schouwenburg, M.G.; Aarts, M.J.; van Akkooi, A.C.; van den Berkmortel, F.; Blank, C.U.; van den Eertwegh, A.J.M.; Franken, M.G.; et al. Metastatic Uveal Melanoma: Treatment Strategies and Survival-Results from the Dutch Melanoma Treatment Registry. Cancers 2019, 11, 1007. [CrossRef] [PubMed]

13. Seedor, R.S.; Eschelman, D.J.; Gonsalves, C.F.; Adamo, R.D.; Orloff, M.; Amjad, A.; Sharpe-Mills, E.; Chervoneva, I.; Shields, C.L.; Shields, J.A.; et al. An Outcome Assessment of a Single Institution's Longitudinal Experience with Uveal Melanoma Patients with Liver Metastasis. Cancers 2020, 12, 117. [CrossRef]

14. Pelster, M.S.; Gruschkus, S.K.; Bassett, R.; Gombos, D.S.; Shephard, M.; Posada, L.; Glover, M.S.; Simien, R.; Diab, A.; Hwu, P.; et al. Nivolumab and Ipilimumab in Metastatic Uveal Melanoma: Results from a Single-Arm Phase II Study. J. Clin. Oncol. 2021, 39, 599-607. [CrossRef] [PubMed] 
15. Rantala, E.S.; Hernberg, M.; Kivela, T.T. Overall survival after treatment for metastatic uveal melanoma: A systematic review and meta-analysis. Melanoma Res. 2019, 29, 561-568. [CrossRef]

16. Rietschel, P.; Panageas, K.S.; Hanlon, C.; Patel, A.; Abramson, D.H.; Chapman, P.B. Variates of Survival in Metastatic Uveal Melanoma. J. Clin. Oncol. 2005, 23, 8076-8080. [CrossRef]

17. Rodriguez-Vidal, C.; Fernandez-Diaz, D.; Fernandez-Marta, B.; Lago-Baameiro, N.; Pardo, M.; Silva, P.; Paniagua, L.; BlancoTeijeiro, M.J.; Pineiro, A.; Bande, M. Treatment of Metastatic Uveal Melanoma: Systematic Review. Cancers 2020, $12,2557$. [CrossRef] [PubMed]

18. Johnson, D.B.; Daniels, A.B. Continued Poor Survival in Metastatic Uveal Melanoma: Implications for Molecular Prognostication, Surveillance Imaging, Adjuvant Therapy, and Clinical Trials. JAMA Ophthalmol. 2018, 136, 986-988. [CrossRef]

19. Algazi, A.P.; Tsai, K.K.; Shoushtari, A.N.; Munhoz, R.R.; Eroglu, Z.; Piulats, J.M.; Ott, P.A.; Johnson, D.B.; Hwang, J.; Daud, A.I.; et al. Clinical outcomes in metastatic uveal melanoma treated with PD-1 and PD-L1 antibodies. Cancer 2016, 122, 3344-3353. [CrossRef]

20. Schank, T.E.; Hassel, J.C. Immunotherapies for the Treatment of Uveal Melanoma-History and Future. Cancers 2019, 11, 1048. [CrossRef]

21. Bol, K.F.; Ellebaek, E.; Hoejberg, L.; Bagger, M.M.; Larsen, M.S.; Klausen, T.W.; Kohler, U.H.; Schmidt, H.; Bastholt, L.; Kiilgaard, J.F.; et al. Real-World Impact of Immune Checkpoint Inhibitors in Metastatic Uveal Melanoma. Cancers 2019, 11, 1489. [CrossRef]

22. Heppt, M.V.; Amaral, T.; Kahler, K.C.; Heinzerling, L.; Hassel, J.C.; Meissner, M.; Kreuzberg, N.; Loquai, C.; Reinhardt, L.; Utikal, J.; et al. Combined immune checkpoint blockade for metastatic uveal melanoma: A retrospective, multi-center study. J. Immunother. Cancer 2019, 7, 299. [CrossRef]

23. Piulats, J.M.; Espinosa, E.; de la Cruz Merino, L.; Varela, M.; Alonso Carrion, L.; Martin-Algarra, S.; Lopez Castro, R.; Curiel, T.; Rodriguez-Abreu, D.; Redrado, M.; et al. Nivolumab Plus Ipilimumab for Treatment-Naive Metastatic Uveal Melanoma: An Open-Label, Multicenter, Phase II Trial by the Spanish Multidisciplinary Melanoma Group (GEM-1402). J. Clin. Oncol. 2021, 39, 586-598. [CrossRef] [PubMed]

24. Larkin, J.; Chiarion-Sileni, V.; Gonzalez, R.; Grob, J.J.; Rutkowski, P.; Lao, C.D.; Cowey, C.L.; Schadendorf, D.; Wagstaff, J.; Dummer, R.; et al. Five-Year Survival with Combined Nivolumab and Ipilimumab in Advanced Melanoma. N. Engl. J. Med. 2019, 381, 1535-1546. [CrossRef] [PubMed]

25. Wolchok, J.D.; Chiarion-Sileni, V.; Gonzalez, R.; Grob, J.-J.; Rutkowski, P.; Lao, C.D.; Cowey, C.L.; Schadendorf, D.; Wagstaff, J.; Dummer, R.; et al. CheckMate 067: 6.5-year outcomes in patients (pts) with advanced melanoma. J. Clin. Oncol. 2021, $39,9506$. [CrossRef]

26. Cancer Genome Atlas, N. Genomic Classification of Cutaneous Melanoma. Cell 2015, 161, 1681-1696. [CrossRef]

27. Robertson, A.G.; Shih, J.; Yau, C.; Gibb, E.A.; Oba, J.; Mungall, K.L.; Hess, J.M.; Uzunangelov, V.; Walter, V.; Danilova, L.; et al. Integrative Analysis Identifies Four Molecular and Clinical Subsets in Uveal Melanoma. Cancer Cell 2017, 32, $204-220 . e 15$. [CrossRef] [PubMed]

28. Bakhoum, M.F.; Esmaeli, B. Molecular Characteristics of Uveal Melanoma: Insights from the Cancer Genome Atlas (TCGA) Project. Cancers 2019, 11, 1061. [CrossRef] [PubMed]

29. Johansson, P.A.; Brooks, K.; Newell, F.; Palmer, J.M.; Wilmott, J.S.; Pritchard, A.L.; Broit, N.; Wood, S.; Carlino, M.S.; Leonard, C.; et al. Whole genome landscapes of uveal melanoma show an ultraviolet radiation signature in iris tumours. Nat. Commun. 2020, 11, 2408. [CrossRef] [PubMed]

30. Royer-Bertrand, B.; Torsello, M.; Rimoldi, D.; El Zaoui, I.; Cisarova, K.; Pescini-Gobert, R.; Raynaud, F.; Zografos, L.; Schalenbourg, A.; Speiser, D.; et al. Comprehensive Genetic Landscape of Uveal Melanoma by Whole-Genome Sequencing. Am. J. Hum. Genet. 2016, 99, 1190-1198. [CrossRef]

31. Vichitvejpaisal, P.; Dalvin, L.A.; Mazloumi, M.; Ewens, K.G.; Ganguly, A.; Shields, C.L. Genetic Analysis of Uveal Melanoma in 658 Patients Using the Cancer Genome Atlas Classification of Uveal Melanoma as A, B, C, and D. Ophthalmology 2019, 126, 1445-1453. [CrossRef] [PubMed]

32. Rodrigues, M.; Mobuchon, L.; Houy, A.; Fiévet, A.; Gardrat, S.; Barnhill, R.L.; Popova, T.; Servois, V.; Rampanou, A.; Mouton, A.; et al. Outlier response to anti-PD1 in uveal melanoma reveals germline MBD4 mutations in hypermutated tumors. Nat. Commun. 2018, 9, 1866. [CrossRef] [PubMed]

33. Rodrigues, M.; Mobuchon, L.; Houy, A.; Alsafadi, S.; Baulande, S.; Mariani, O.; Marande, B.; Ait Rais, K.; Van der Kooij, M.K.; Kapiteijn, E.; et al. Evolutionary Routes in Metastatic Uveal Melanomas Depend on MBD4 Alterations. Clin. Cancer Res. 2019, 25, 5513-5524. [CrossRef]

34. Repo, P.; Jantti, J.E.; Jarvinen, R.S.; Rantala, E.S.; Tall, M.; Raivio, V.; Kivela, T.T.; Turunen, J.A. Germline loss-of-function variants in MBD4 are rare in Finnish patients with uveal melanoma. Pigment. Cell Melanoma Res. 2020, 33, 756-762. [CrossRef] [PubMed]

35. Harbour, J.W. The genetics of uveal melanoma: An emerging framework for targeted therapy. Pigment. Cell Melanoma Res. 2012, 25, 171-181. [CrossRef] [PubMed]

36. Karlsson, J.; Nilsson, L.M.; Mitra, S.; Alsen, S.; Shelke, G.V.; Sah, V.R.; Forsberg, E.M.V.; Stierner, U.; All-Eriksson, C.; Einarsdottir, B.; et al. Molecular profiling of driver events in metastatic uveal melanoma. Nat. Commun. 2020, 11, 1894. [CrossRef]

37. Shain, A.H.; Bagger, M.M.; Yu, R.; Chang, D.; Liu, S.; Vemula, S.; Weier, J.F.; Wadt, K.; Heegaard, S.; Bastian, B.C.; et al. The genetic evolution of metastatic uveal melanoma. Nat. Genet. 2019, 51, 1123-1130. [CrossRef] [PubMed] 
38. Reiter, J.G.; Makohon-Moore, A.P.; Gerold, J.M.; Heyde, A.; Attiyeh, M.A.; Kohutek, Z.A.; Tokheim, C.J.; Brown, A.; DeBlasio, R.M.; Niyazov, J.; et al. Minimal functional driver gene heterogeneity among untreated metastases. Science 2018, 361, $1033-1037$. [CrossRef]

39. Vogelstein, B.; Papadopoulos, N.; Velculescu, V.E.; Zhou, S.; Diaz, L.A., Jr.; Kinzler, K.W. Cancer genome landscapes. Science 2013, 339, 1546-1558. [CrossRef] [PubMed]

40. Hoefsmit, E.P.; Rozeman, E.A.; Van, T.M.; Dimitriadis, P.; Krijgsman, O.; Conway, J.W.; Pires da Silva, I.; van der Wal, J.E.; Ketelaars, S.L.C.; Bresser, K.; et al. Comprehensive analysis of cutaneous and uveal melanoma liver metastases. J. Immunother. Cancer 2020, 8, 1501. [CrossRef]

41. Coupland, S.E.; Lake, S.L.; Zeschnigk, M.; Damato, B.E. Molecular pathology of uveal melanoma. Eye 2013, 27, 230-242. [CrossRef]

42. Kilic, E.; van Gils, W.; Lodder, E.; Beverloo, H.B.; van Til, M.E.; Mooy, C.M.; Paridaens, D.; de Klein, A.; Luyten, G.P. Clinical and cytogenetic analyses in uveal melanoma. Investig. Ophthalmol. Vis. Sci. 2006, 47, 3703-3707. [CrossRef] [PubMed]

43. Hoglund, M.; Gisselsson, D.; Hansen, G.B.; White, V.A.; Sall, T.; Mitelman, F.; Horsman, D. Dissecting karyotypic patterns in malignant melanomas: Temporal clustering of losses and gains in melanoma karyotypic evolution. Int. J. Cancer 2004, 108, 57-65. [CrossRef] [PubMed]

44. van den Bosch, T.; van Beek, J.G.; Vaarwater, J.; Verdijk, R.M.; Naus, N.C.; Paridaens, D.; de Klein, A.; Kilic, E. Higher percentage of FISH-determined monosomy 3 and $8 \mathrm{q}$ amplification in uveal melanoma cells relate to poor patient prognosis. Investig. Ophthalmol. Vis. Sci. 2012, 53, 2668-2674. [CrossRef]

45. White, V.A.; Chambers, J.D.; Courtright, P.D.; Chang, W.Y.; Horsman, D.E. Correlation of cytogenetic abnormalities with the outcome of patients with uveal melanoma. Cancer 1998, 83, 354-359. [CrossRef]

46. Harbour, J.W.; Onken, M.D.; Roberson, E.D.; Duan, S.; Cao, L.; Worley, L.A.; Council, M.L.; Matatall, K.A.; Helms, C.; Bowcock, A.M. Frequent mutation of BAP1 in metastasizing uveal melanomas. Science 2010, 330, 1410-1413. [CrossRef]

47. Mallone, F.; Sacchetti, M.; Lambiase, A.; Moramarco, A. Molecular Insights and Emerging Strategies for Treatment of Metastatic Uveal Melanoma. Cancers 2020, 12, 2761. [CrossRef] [PubMed]

48. Prescher, G.; Bornfeld, N.; Hirche, H.; Horsthemke, B.; Jockel, K.H.; Becher, R. Prognostic implications of monosomy 3 in uveal melanoma. Lancet 1996, 347, 1222-1225. [CrossRef] [PubMed]

49. Derrien, A.-C.; Rodrigues, M.; Eeckhoutte, A.; Dayot, S.; Houy, A.; Mobuchon, L.; Gardrat, S.; Lequin, D.; Ballet, S.; Pierron, G.; et al. Germline MBD4 Mutations and Predisposition to Uveal Melanoma. JNCI J. Natl. Cancer Inst. 2021, 113, 80-87. [CrossRef] [PubMed]

50. Johansson, P.A.; Stark, A.; Palmer, J.M.; Bigby, K.; Brooks, K.; Rolfe, O.; Pritchard, A.L.; Whitehead, K.; Warrier, S.; Glasson, W.; et al. Prolonged stable disease in a uveal melanoma patient with germline MBD4 nonsense mutation treated with pembrolizumab and ipilimumab. Immunogenetics 2019, 71, 433-436. [CrossRef] [PubMed]

51. Onken, M.D.; Worley, L.A.; Ehlers, J.P.; Harbour, J.W. Gene Expression Profiling in Uveal Melanoma Reveals Two Molecular Classes and Predicts Metastatic Death. Cancer Res. 2004, 64, 7205-7209. [CrossRef] [PubMed]

52. Harbour, J.W.; Chen, R. The DecisionDx-UM Gene Expression Profile Test Provides Risk Stratification and Individualized Patient Care in Uveal Melanoma. PLoS Curr. 2013, 5. [CrossRef] [PubMed]

53. Onken, M.D.; Worley, L.A.; Char, D.H.; Augsburger, J.J.; Correa, Z.M.; Nudleman, E.; Aaberg, T.M.; Altaweel, M.M.; Bardenstein, D.S.; Finger, P.T.; et al. Collaborative Ocular Oncology Group Report Number 1: Prospective Validation of a Multi-Gene Prognostic Assay in Uveal Melanoma. Ophthalmology 2012, 119, 1596-1603. [CrossRef] [PubMed]

54. Aaberg, T.M.; Covington, K.R.; Tsai, T.; Shildkrot, Y.; Plasseraud, K.M.; Alsina, K.M.; Oelschlager, K.M.; Monzon, F.A. Gene Expression Profiling in Uveal Melanoma: Five-Year Prospective Outcomes and Meta-Analysis. Ocul. Oncol. Pathol. 2020, 6, 360-367. [CrossRef] [PubMed]

55. Chang, S.-H.; Worley, L.A.; Onken, M.D.; Harbour, J.W. Prognostic biomarkers in uveal melanoma: Evidence for a stem cell-like phenotype associated with metastasis. Melanoma Res. 2008, 18, 191-200. [CrossRef] [PubMed]

56. Onken, M.D.; Ehlers, J.P.; Worley, L.A.; Makita, J.; Yokota, Y.; Harbour, J.W. Functional Gene Expression Analysis Uncovers Phenotypic Switch in Aggressive Uveal Melanomas. Cancer Res. 2006, 66, 4602-4609. [CrossRef] [PubMed]

57. Cai, L.; Paez-Escamilla, M.; Walter, S.D.; Tarlan, B.; Decatur, C.L.; Perez, B.M.; Harbour, J.W. Gene Expression Profiling and PRAME Status Versus Tumor-Node-Metastasis Staging for Prognostication in Uveal Melanoma. Am. J. Ophthalmol. 2018, 195, 154-160. [CrossRef] [PubMed]

58. Van Raamsdonk, C.D.; Griewank, K.G.; Crosby, M.B.; Garrido, M.C.; Vemula, S.; Wiesner, T.; Obenauf, A.C.; Wackernagel, W.; Green, G.; Bouvier, N.; et al. Mutations in GNA11 in uveal melanoma. N. Engl. J. Med. 2010, 363, 2191-2199. [CrossRef] [PubMed]

59. Van Raamsdonk, C.D.; Bezrookove, V.; Green, G.; Bauer, J.; Gaugler, L.; O’Brien, J.M.; Simpson, E.M.; Barsh, G.S.; Bastian, B.C. Frequent somatic mutations of GNAQ in uveal melanoma and blue naevi. Nature 2009, 457, 599-602. [CrossRef] [PubMed]

60. Johansson, P.; Aoude, L.G.; Wadt, K.; Glasson, W.J.; Warrier, S.K.; Hewitt, A.W.; Kiilgaard, J.F.; Heegaard, S.; Isaacs, T.; Franchina, M.; et al. Deep sequencing of uveal melanoma identifies a recurrent mutation in PLCB4. Oncotarget 2016, 7, 4624-4631. [CrossRef] [PubMed]

61. Moore, A.R.; Ceraudo, E.; Sher, J.J.; Guan, Y.; Shoushtari, A.N.; Chang, M.T.; Zhang, J.Q.; Walczak, E.G.; Kazmi, M.A.; Taylor, B.S.; et al. Recurrent activating mutations of G-protein-coupled receptor CYSLTR2 in uveal melanoma. Nat. Genet. 2016, 48, 675-680. [CrossRef] [PubMed] 
62. Vivet-Noguer, R.; Tarin, M.; Roman-Roman, S.; Alsafadi, S. Emerging Therapeutic Opportunities Based on Current Knowledge of Uveal Melanoma Biology. Cancers 2019, 11, 1019. [CrossRef] [PubMed]

63. Bauer, J.; Kilic, E.; Vaarwater, J.; Bastian, B.C.; Garbe, C.; De Klein, A. Oncogenic GNAQ mutations are not correlated with disease-free survival in uveal melanoma. Br. J. Cancer 2009, 101, 813-815. [CrossRef] [PubMed]

64. Onken, M.D.; Worley, L.A.; Long, M.D.; Duan, S.; Council, M.L.; Bowcock, A.M.; Harbour, J.W. Oncogenic Mutations inGNAQOccur Early in Uveal Melanoma. Investig. Opthalmology Vis. Sci. 2008, 49, 5230. [CrossRef] [PubMed]

65. Van Weeghel, C.; Wierenga, A.P.A.; Versluis, M.; Van Hall, T.; Van Der Velden, P.A.; Kroes, W.G.M.; Pfeffer, U.; Luyten, G.P.M.; Jager, M.J. Do GNAQ and GNA11 Differentially Affect Inflammation and HLA Expression in Uveal Melanoma? Cancers 2019, 11, 1127. [CrossRef] [PubMed]

66. Terai, M.; Orloff, M.; Sugase, T.; Thomas, J.; Daneilson, M.; Sharpe-Mills, E.; Aplin, A.; Sato, T. Somatic mutations and their impact on survival in metastatic uveal melanoma. Pigment. Cell Melanoma Res. 2000, 33, 148-255. [CrossRef]

67. Ewens, K.G.; Kanetsky, P.A.; Richards-Yutz, J.; Purrazzella, J.; Shields, C.L.; Ganguly, T.; Ganguly, A. Chromosome 3 Status Combined WithBAP1andEIF1AXMutation Profiles Are Associated with Metastasis in Uveal Melanoma. Investig. Opthalmology Vis. Sci. 2014, 55, 5160. [CrossRef]

68. Martin, M.; Maßhöfer, L.; Temming, P.; Rahmann, S.; Metz, C.; Bornfeld, N.; Van De Nes, J.; Klein-Hitpass, L.; Hinnebusch, A.G.; Horsthemke, B.; et al. Exome sequencing identifies recurrent somatic mutations in EIF1AX and SF3B1 in uveal melanoma with disomy 3. Nat. Genet. 2013, 45, 933-936. [CrossRef]

69. Yavuzyigitoglu, S.; Koopmans, A.E.; Verdijk, R.M.; Vaarwater, J.; Eussen, B.; van Bodegom, A.; Paridaens, D.; Kilic, E.; de Klein, A.; Rotterdam Ocular Melanoma Study Group. Uveal Melanomas with SF3B1 Mutations: A Distinct Subclass Associated with Late-Onset Metastases. Ophthalmology 2016, 123, 1118-1128. [CrossRef]

70. Etemadmoghadam, D.; Azar, W.J.; Lei, Y.; Moujaber, T.; Garsed, D.W.; Kennedy, C.J.; Fereday, S.; Mitchell, C.; Chiew, Y.-E.; Hendley, J.; et al. EIF1AX and NRAS Mutations Co-occur and Cooperate in Low-Grade Serous Ovarian Carcinomas. Cancer Res. 2017, 77, 4268-4278. [CrossRef]

71. Krishnamoorthy, G.P.; Davidson, N.R.; Leach, S.D.; Zhao, Z.; Lowe, S.W.; Lee, G.; Landa, I.; Nagarajah, J.; Saqcena, M.; Singh, K.; et al. EIF1AX and RAS Mutations Cooperate to Drive Thyroid Tumorigenesis through ATF4 and c-MYC. Cancer Discov. 2019, 9, 264-281. [CrossRef]

72. Zhou, Z.; Gong, Q.; Wang, Y.; Li, M.; Wang, L.; Ding, H.; Li, P. The biological function and clinical significance of SF3B1 mutations in cancer. Biomark. Res. 2020, 8, 38. [CrossRef] [PubMed]

73. Mergener, S.; Siveke, J.T.; Peña-Llopis, S. Monosomy 3 Is Linked to Resistance to MEK Inhibitors in Uveal Melanoma. Int. J. Mol. Sci. 2021, 22, 6727. [CrossRef]

74. Aoude, L.G.; Vajdic, C.M.; Kricker, A.; Armstrong, B.; Hayward, N.K. Prevalence of germline BAP1 mutation in a population-based sample of uveal melanoma cases. Pigment. Cell Melanoma Res. 2013, 26, 278-279. [CrossRef] [PubMed]

75. Gupta, M.P.; Lane, A.M.; Deangelis, M.M.; Mayne, K.; Crabtree, M.; Gragoudas, E.S.; Kim, I.K. Clinical Characteristics of Uveal Melanoma in Patients with GermlineBAP1Mutations. JAMA Ophthalmol. 2015, 133, 881. [CrossRef]

76. Turunen, J.A.; Markkinen, S.; Wilska, R.; Saarinen, S.; Raivio, V.; Täll, M.; Lehesjoki, A.-E.; Kivela, T.T. BAP1 Germline Mutations in Finnish Patients with Uveal Melanoma. Ophthalmology 2016, 123, 1112-1117. [CrossRef] [PubMed]

77. Huang, K.-L.; Mashl, R.J.; Wu, Y.; Ritter, D.I.; Wang, J.; Oh, C.; Paczkowska, M.; Reynolds, S.; Wyczalkowski, M.A.; Oak, N.; et al. Pathogenic Germline Variants in 10,389 Adult Cancers. Cell 2018, 173, 355-370.e14. [CrossRef]

78. Masoomian, B.; Shields, J.A.; Shields, C.L. Overview of BAP1 cancer predisposition syndrome and the relationship to uveal melanoma. J. Curr. Ophthalmol. 2018, 30, 102-109. [CrossRef]

79. Rai, K.; Pilarski, R.; Cebulla, C.M.; Abdel-Rahman, M.H. Comprehensive review of BAP1 tumor predisposition syndrome with report of two new cases. Clin. Genet. 2016, 89, 285-294. [CrossRef]

80. Pilarski, R.; Carlo, M.; Cebulla, C.; Abdel-Rahman, M. BAP1 Tumor Predisposition Syndrome. In GeneReviews ( $\left.{ }^{\circledR}\right)$; Adam, M.P., Ardinger, H.H., Pagon, R.A., Wallace, S.E., Bean, L.J.H., Mirzaa, G., Amemiya, A., Eds.; University of Washington: Seattle, DC, USA, 2020.

81. Singh, N.; Singh, R.; Bowen, R.C.; Abdel-Rahman, M.H.; Singh, A.D. Uveal Melanoma in BAP1 Tumor Predisposition Syndrome: Estimation of Risk. Am. J. Ophthalmol. 2021, 224, 172-177. [CrossRef]

82. Star, P.; Goodwin, A.; Kapoor, R.; Conway, R.M.; Long, G.V.; Scolyer, R.A.; Guitera, P. Germline BAP1-positive patients: The dilemmas of cancer surveillance and a proposed interdisciplinary consensus monitoring strategy. Eur. J. Cancer 2018, 92, 48-53. [CrossRef]

83. Carbone, M.; Ferris, L.K.; Baumann, F.; Napolitano, A.; Lum, C.A.; Flores, E.G.; Gaudino, G.; Powers, A.; Bryant-Greenwood, P.; Krausz, T.; et al. BAP1 cancer syndrome: Malignant mesothelioma, uveal and cutaneous melanoma, and MBAITs. J. Transl. Med. 2012, 10, 179. [CrossRef] [PubMed]

84. Battaglia, A. The Importance of Multidisciplinary Approach in Early Detection of BAP1 Tumor Predisposition Syndrome: Clinical Management and Risk Assessment. Clin. Med. Insights Oncol. 2014, 8, 37-47. [CrossRef] [PubMed]

85. Pilarski, R.; Cebulla, C.M.; Massengill, J.B.; Rai, K.; Rich, T.; Strong, L.; McGillivray, B.; Asrat, M.-J.; Davidorf, F.H.; Abdel-Rahman, M.H. Expanding the clinical phenotype of hereditaryBAP1cancer predisposition syndrome, reporting three new cases. Genes Chromosomes Cancer 2014, 53, 177-182. [CrossRef] [PubMed] 
86. Njauw, C.-N.J.; Kim, I.; Piris, A.; Gabree, M.; Taylor, M.; Lane, A.M.; Deangelis, M.M.; Gragoudas, E.; Duncan, L.M.; Tsao, H. Germline BAP1 Inactivation Is Preferentially Associated with Metastatic Ocular Melanoma and Cutaneous-Ocular Melanoma Families. PLoS ONE 2012, 7, e35295. [CrossRef] [PubMed]

87. Ewens, K.G.; Lalonde, E.; Richards-Yutz, J.; Shields, C.L.; Ganguly, A. Comparison of Germline versus Somatic BAP1 Mutations for Risk of Metastasis in Uveal Melanoma. BMC Cancer 2018, 18, 1172. [CrossRef]

88. Walpole, S.; Pritchard, A.L.; Cebulla, C.M.; Pilarski, R.; Stautberg, M.; Davidorf, F.H.; De La Fouchardière, A.; Cabaret, O.; Golmard, L.; Stoppa-Lyonnet, D.; et al. Comprehensive Study of the Clinical Phenotype of GermlineBAP1Variant-Carrying Families Worldwide. JNCI J. Natl. Cancer Inst. 2018, 110, 1328-1341. [CrossRef] [PubMed]

89. Shields, C.L.; Furuta, M.; Thangappan, A.; Nagori, S.; Mashayekhi, A.; Lally, D.R.; Kelly, C.C.; Rudich, D.S.; Nagori, A.V.; Wakade, O.A.; et al. Metastasis of uveal melanoma millimeter-by-millimeter in 8033 consecutive eyes. Arch. Ophthalmol. 2009, 127, 989-998. [CrossRef] [PubMed]

90. Shields, C.L.; Kaliki, S.; Furuta, M.; Fulco, E.; Alarcon, C.; Shields, J.A. American Joint Committee on Cancer classification of posterior uveal melanoma (tumor size category) predicts prognosis in 7731 patients. Ophthalmology 2013, 120, $2066-2071$. [CrossRef] [PubMed]

91. Kaliki, S.; Shields, C.L.; Shields, J.A. Uveal melanoma: Estimating prognosis. Indian J. Ophthalmol. 2015, 63, 93-102. [CrossRef] [PubMed]

92. Barisione, G.; Fabbi, M.; Gino, A.; Queirolo, P.; Orgiano, L.; Spano, L.; Picasso, V.; Pfeffer, U.; Mosci, C.; Jager, M.J.; et al. Potential Role of Soluble c-Met as a New Candidate Biomarker of Metastatic Uveal Melanoma. JAMA Ophthalmol. 2015, $133,1013$. [CrossRef] [PubMed]

93. National Comprehensive Cancer Network. Melanoma: Uveal (Version 2.2021). Available online: https://www.nccn.org/ professionals/physician_gls/pdf/uveal.pdf (accessed on 2 August 2021).

94. Marshall, E.; Romaniuk, C.; Ghaneh, P.; Wong, H.; McKay, M.; Chopra, M.; Coupland, S.E.; Damato, B.E. MRI in the detection of hepatic metastases from high-risk uveal melanoma: A prospective study in 188 patients. Br. J. Ophthalmol. 2013, 97, 159-163. [CrossRef] [PubMed]

95. Wen, J.C.; Sai, V.; Straatsma, B.R.; McCannel, T.A. Radiation-Related Cancer Risk Associated with Surveillance Imaging for Metastasis from Choroidal Melanoma. JAMA Ophthalmol. 2013, 131, 56. [CrossRef]

96. Orcurto, V.; Denys, A.; Voelter, V.; Schalenbourg, A.; Schnyder, P.; Zografos, L.; Leyvraz, S.; Delaloye, A.B.; Prior, J.O. 18Ffluorodeoxyglucose positron emission tomography/computed tomography and magnetic resonance imaging in patients with liver metastases from uveal melanoma. Melanoma Res. 2012, 22, 63-69. [CrossRef]

97. Gonsalves, C.F.; Eschelman, D.J.; Sullivan, K.L.; Anne, P.R.; Doyle, L.; Sato, T. Radioembolization as Salvage Therapy for Hepatic Metastasis of Uveal Melanoma: A Single-Institution Experience. Am. J. Roentgenol. 2011, 196, 468-473. [CrossRef] [PubMed]

98. Gupta, S.; Bedikian, A.Y.; Ahrar, J.; Ensor, J.; Ahrar, K.; Madoff, D.C.; Wallace, M.J.; Murthy, R.; Tam, A.; Hwu, P. Hepatic artery chemoembolization in patients with ocular melanoma metastatic to the liver: Response, survival, and prognostic factors. Am. J. Clin. Oncol. 2010, 33, 474-480. [CrossRef] [PubMed]

99. Hsueh, E.C.; Essner, R.; Foshag, L.J.; Ye, X.; Wang, H.-J.; Morton, D.L. Prolonged survival after complete resection of metastases from intraocular melanoma. Cancer 2004, 100, 122-129. [CrossRef]

100. Huppert, P.E.; Fierlbeck, G.; Pereira, P.; Schanz, S.; Duda, S.H.; Wietholtz, H.; Rozeik, C.; Claussen, C.D. Transarterial chemoembolization of liver metastases in patients with uveal melanoma. Eur. J. Radiol. 2010, 74, e38-e44. [CrossRef] [PubMed]

101. Mariani, P.; Piperno-Neumann, S.; Servois, V.; Berry, M.G.; Dorval, T.; Plancher, C.; Couturier, J.; Levy-Gabriel, C.; Lumbroso-Le Rouic, L.; Desjardins, L.; et al. Surgical management of liver metastases from uveal melanoma: 16 years' experience at the Institut Curie. Eur. J. Surg. Oncol. 2009, 35, 1192-1197. [CrossRef] [PubMed]

102. Patel, K.; Sullivan, K.; Berd, D.; Mastrangelo, M.J.; Shields, C.L.; Shields, J.A.; Sato, T. Chemoembolization of the hepatic artery with BCNU for metastatic uveal melanoma: Results of a phase II study. Melanoma Res. 2005, 15, 297-304. [CrossRef] [PubMed]

103. Gomez, D.; Wetherill, C.; Cheong, J.; Jones, L.; Marshall, E.; Damato, B.; Coupland, S.E.; Ghaneh, P.; Poston, G.J.; Malik, H.Z.; et al. The Liverpool uveal melanoma liver metastases pathway: Outcome following liver resection. J. Surg. Oncol. 2014, 109, 542-547. [CrossRef] [PubMed]

104. Middleton, M.R.; McAlpine, C.; Woodcock, V.K.; Corrie, P.; Infante, J.R.; Steven, N.M.; Evans, T.R.J.; Anthoney, A.; Shoushtari, A.N.; Hamid, O.; et al. Tebentafusp, A TCR/Anti-CD3 Bispecific Fusion Protein Targeting gp100, Potently Activated Antitumor Immune Responses in Patients with Metastatic Melanoma. Clin. Cancer Res. 2020, 26, 5869-5878. [CrossRef]

105. Blohmer, J.U.; Rezai, M.; Kümmel, S.; Kühn, T.; Warm, M.; Friedrichs, K.; Benkow, A.; Valentine, W.J.; Eiermann, W. Using the 21-gene assay to guide adjuvant chemotherapy decision-making in early-stage breast cancer: A cost-effectiveness evaluation in the German setting. J. Med. Econ. 2013, 16, 30-40. [CrossRef] [PubMed]

106. Reed, S.D.; Dinan, M.A.; Schulman, K.A.; Lyman, G.H. Cost-effectiveness of the 21-gene recurrence score assay in the context of multifactorial decision making to guide chemotherapy for early-stage breast cancer. Genet. Med. 2013, 15, 203-211. [CrossRef]

107. Vataire, A.L.; Laas, E.; Aballea, S.; Gligorov, J.; Rouzier, R.; Chereau, E. Cost-effectiveness of a chemotherapy predictive test. Bull. Cancer 2012, 99, 907-914. [CrossRef] [PubMed]

108. Aaberg, T.M., Jr.; Cook, R.W.; Oelschlager, K.; Maetzold, D.; Rao, P.K.; Mason, J.O., 3rd. Current clinical practice: Differential management of uveal melanoma in the era of molecular tumor analyses. Clin. Ophthalmol. 2014, 8, 2449-2460. [CrossRef] [PubMed] 
109. Davanzo, J.M.; Binkley, E.M.; Bena, J.F.; Singh, A.D. Risk-stratified systemic surveillance in uveal melanoma. Br. J. Ophthalmol. 2019, 103, 1868-1871. [CrossRef] [PubMed]

110. Plasseraud, K.M.; Cook, R.W.; Tsai, T.; Shildkrot, Y.; Middlebrook, B.; Maetzold, D.; Wilkinson, J.; Stone, J.; Johnson, C.; Oelschlager, K.; et al. Clinical Performance and Management Outcomes with the DecisionDx-UM Gene Expression Profile Test in a Prospective Multicenter Study. J. Oncol. 2016, 2016, 1-9. [CrossRef] [PubMed]

111. Schefler, A.C.; Skalet, A.; Oliver, S.C.; Mason, J.; Daniels, A.B.; Alsina, K.M.; Plasseraud, K.M.; Monzon, F.A.; Firestone, B. Prospective evaluation of risk-appropriate management of uveal melanoma patients informed by gene expression profiling. Melanoma Manag. 2020, 7, MMT37. [CrossRef] [PubMed]

112. Beran, T.M.; McCannel, T.A.; Stanton, A.L.; Straatsma, B.R.; Burgess, B.L. Reactions to and Desire for Prognostic Testing in Choroidal Melanoma Patients. J. Genet. Couns. 2009, 18, 265-274. [CrossRef] [PubMed]

113. Cook, S.A.; Damato, B.; Marshall, E.; Salmon, P. Psychological aspects of cytogenetic testing of uveal melanoma: Preliminary findings and directions for future research. Eye 2009, 23, 581-585. [CrossRef] [PubMed]

114. Mahipal, A.; Tijani, L.; Chan, K.; Laudadio, M.; Mastrangelo, M.J.; Sato, T. A pilot study of sunitinib malate in patients with metastatic uveal melanoma. Melanoma Res. 2012, 22, 440-446. [CrossRef]

115. Valsecchi, M.E.; Orloff, M.; Sato, R.; Chervoneva, I.; Shields, C.L.; Shields, J.A.; Mastrangelo, M.J.; Sato, T. Adjuvant Sunitinib in High-Risk Patients with Uveal Melanoma: Comparison with Institutional Controls. Ophthalmology 2018, 125, 210-217. [CrossRef]

116. Sato, T.; Orloff, M.M.; Valsecchi, M.E.; Shimada, A.; Chervoneva, I.; Sharpe-Mills, E.; Klose, H.; Norcini, J.; Belinsky, J.; Sato, S.; et al. A randomized phase II study of adjuvant sunitinib or valproic acid in high-risk patients with uveal melanoma. J. Clin. Oncol. 2020, 38, e22059. [CrossRef]

117. Surriga, O.; Rajasekhar, V.K.; Ambrosini, G.; Dogan, Y.; Huang, R.; Schwartz, G.K. Crizotinib, a c-Met Inhibitor, Prevents Metastasis in a Metastatic Uveal Melanoma Model. Mol. Cancer Ther. 2013, 12, 2817-2826. [CrossRef] [PubMed]

118. Khan, S.; Lutzky, J.; Shoushtari, A.N.; Jeter, J.M.; Chiuzan, C.; Sender, N.; Blumberg, L.E.; Nesson, A.; Singh-Kandah, S.V.; Hernandez, S.; et al. Adjuvant crizotinib in high-risk uveal melanoma following definitive therapy. J. Clin. Oncol. 2020, $38,10075$. [CrossRef]

119. Bol, K.F.; van den Bosch, T.; Schreibelt, G.; Mensink, H.W.; Keunen, J.E.; Kilic, E.; Japing, W.J.; Geul, K.W.; Westdorp, H.; Boudewijns, S.; et al. Adjuvant Dendritic Cell Vaccination in High-Risk Uveal Melanoma. Ophthalmology 2016, 123, $2265-2267$. [CrossRef]

120. Fountain, E.; Bassett, R.; Cain, S.; Posada, L.; Gombos, D.; Hwu, P.; Bedikian, A.; Patel, S. Adjuvant Ipilimumab in High-Risk Uveal Melanoma. Cancers 2019, 11, 152. [CrossRef] [PubMed]

121. Croce, M.; Ferrini, S.; Pfeffer, U.; Gangemi, R. Targeted Therapy of Uveal Melanoma: Recent Failures and New Perspectives. Cancers 2019, 11, 846. [CrossRef] [PubMed]

122. Xiong, X.F.; Zhang, H.; Boesgaard, M.W.; Underwood, C.R.; Brauner-Osborne, H.; Stromgaard, K. Structure-Activity Relationship Studies of the Natural Product Gq/11 Protein Inhibitor YM-254890. ChemMedChem 2019, 14, 865-870. [CrossRef] [PubMed]

123. Schrage, R.; Schmitz, A.-L.; Gaffal, E.; Annala, S.; Kehraus, S.; Wenzel, D.; Büllesbach, K.M.; Bald, T.; Inoue, A.; Shinjo, Y.; et al. The experimental power of FR900359 to study Gq-regulated biological processes. Nat. Commun. 2015, 6, 10156. [CrossRef] [PubMed]

124. Lapadula, D.; Farias, E.; Randolph, C.E.; Purwin, T.J.; McGrath, D.; Charpentier, T.H.; Zhang, L.; Wu, S.; Terai, M.; Sato, T.; et al. Effects of Oncogenic G $\alpha q$ and G $\alpha 11$ Inhibition by FR900359 in Uveal Melanoma. Mol. Cancer Res. 2019, 17, 963-973. [CrossRef]

125. Onken, M.D.; Makepeace, C.M.; Kaltenbronn, K.M.; Kanai, S.M.; Todd, T.D.; Wang, S.; Broekelmann, T.J.; Rao, P.K.; Cooper, J.A.; Blumer, K.J. Targeting nucleotide exchange to inhibit constitutively active G protein $\alpha$ subunits in cancer cells. Sci. Signal. 2018, 11, eaao6852. [CrossRef] [PubMed]

126. Yoo, J.H.; Shi, D.S.; Grossmann, A.H.; Sorensen, L.K.; Tong, Z.; Mleynek, T.M.; Rogers, A.; Zhu, W.; Richards, J.R.; Winter, J.M.; et al. ARF6 Is an Actionable Node that Orchestrates Oncogenic GNAQ Signaling in Uveal Melanoma. Cancer Cell 2016, 29, 889-904. [CrossRef] [PubMed]

127. Buchbinder, E.I.; Cohen, J.V.; Haq, R.; Hodi, F.S.; Lawrence, D.P.; Giobbie-Hurder, A.; Knoerzer, D.; Sullivan, R.J. A phase II study of ERK inhibition by ulixertinib (BVD-523) in metastatic uveal melanoma. J. Clin. Oncol. 2020, 38, 10036. [CrossRef]

128. Steeb, T.; Wessely, A.; Ruzicka, T.; Heppt, M.V.; Berking, C. How to MEK the best of uveal melanoma: A systematic review on the efficacy and safety of MEK inhibitors in metastatic or unresectable uveal melanoma. Eur. J. Cancer 2018, 103, 41-51. [CrossRef] [PubMed]

129. Carvajal, R.D.; Piperno-Neumann, S.; Kapiteijn, E.; Chapman, P.B.; Frank, S.; Joshua, A.M.; Piulats, J.M.; Wolter, P.; Cocquyt, V.; Chmielowski, B.; et al. Selumetinib in Combination with Dacarbazine in Patients with Metastatic Uveal Melanoma: A Phase III, Multicenter, Randomized Trial (SUMIT). J. Clin. Oncol. 2018, 36, 1232-1239. [CrossRef]

130. Carvajal, R.D.; Sosman, J.A.; Quevedo, J.F.; Milhem, M.M.; Joshua, A.M.; Kudchadkar, R.R.; Linette, G.P.; Gajewski, T.F.; Lutzky, J.; Lawson, D.H.; et al. Effect of selumetinib vs. chemotherapy on progression-free survival in uveal melanoma: A randomized clinical trial. JAMA 2014, 311, 2397-2405. [CrossRef] [PubMed]

131. Kirkwood, J.M.; Bastholt, L.; Robert, C.; Sosman, J.; Larkin, J.; Hersey, P.; Middleton, M.; Cantarini, M.; Zazulina, V.; Kemsley, K.; et al. Phase II, Open-Label, Randomized Trial of the MEK1/2 Inhibitor Selumetinib as Monotherapy versus Temozolomide in Patients with Advanced Melanoma. Clin. Cancer Res. 2012, 18, 555-567. [CrossRef] 
132. Shoushtari, A.N.; Kudchadkar, R.R.; Panageas, K.; Murthy, R.K.; Jung, M.; Shah, R.; O’Donnell, B.; Khawaja, T.T.; Shames, Y.; Prempeh-Keteku, N.A.; et al. A randomized phase 2 study of trametinib with or without GSK2141795 in patients with advanced uveal melanoma. J. Clin. Oncol. 2016, 34, 9511. [CrossRef]

133. Falchook, G.S.; Lewis, K.D.; Infante, J.R.; Gordon, M.S.; Vogelzang, N.J.; DeMarini, D.J.; Sun, P.; Moy, C.; Szabo, S.A.; Roadcap, L.T.; et al. Activity of the oral MEK inhibitor trametinib in patients with advanced melanoma: A phase 1 dose-escalation trial. Lancet Oncol. 2012, 13, 782-789. [CrossRef]

134. Mackeigan, J.P.; Collins, T.S.; Ting, J.P.Y. MEK Inhibition Enhances Paclitaxel-induced Tumor Apoptosis. J. Biol. Chem. 2000, 275, 38953-38956. [CrossRef] [PubMed]

135. Fizazi, K.; Maillard, A.; Penel, N.; Baciarello, G.; Allouache, D.; Daugaard, G.; Van De Wouw, A.; Soler, G.; Vauleon, E.; Chaigneau, L.; et al. A phase III trial of empiric chemotherapy with cisplatin and gemcitabine or systemic treatment tailored by molecular gene expression analysis in patients with carcinomas of an unknown primary (CUP) site (GEFCAPI 04). Ann. Oncol. 2019, 30, v851. [CrossRef]

136. Decaudin, D.; El Botty, R.; Diallo, B.; Massonnet, G.; Fleury, J.; Naguez, A.; Raymondie, C.; Davies, E.; Smith, A.; Wilson, J.; et al. Selumetinib-based therapy in uveal melanoma patient-derived xenografts. Oncotarget 2018, 9, 21674-21686. [CrossRef] [PubMed]

137. Piperno-Neumann, S.; Kapiteijn, E.; Larkin, J.M.G.; Carvajal, R.D.; Luke, J.J.; Seifert, H.; Roozen, I.; Zoubir, M.; Yang, L.; Choudhury, S.; et al. Phase I dose-escalation study of the protein kinase C (PKC) inhibitor AEB071 in patients with metastatic uveal melanoma. J. Clin. Oncol. 2014, 32, 9030. [CrossRef]

138. Kapiteijn, E.; Carlino, M.; Boni, V.; Loirat, D.; Speetjens, F.; Park, J.; Calvo, E.; Carvajal, R.; Nyakas, M.; Gonzalez-Maffe, J.; et al. Abstract CT068: A phase I trial of LXS196, a novel PKC inhibitor for metastatic uveal melanoma. AACR 2019, CT068. [CrossRef]

139. IDEAYA Biosciences Corporate Presentation. July 2021. Available online: https://ir.ideayabio.com/image/20210712_IDEAYA_ Investor+-+Corporate+Presentation+\%28Jul+2021\%29_vF.pdf (accessed on 8 August 2021).

140. Carita, G.; Frisch-Dit-Leitz, E.; Dahmani, A.; Raymondie, C.; Cassoux, N.; Piperno-Neumann, S.; Némati, F.; Laurent, C.; De Koning, L.; Halilovic, E.; et al. Dual inhibition of protein kinase C and p53-MDM2 or PKC and mTORC1 are novel efficient therapeutic approaches for uveal melanoma. Oncotarget 2016, 7, 33542-33556. [CrossRef] [PubMed]

141. Shoushtari, A.N.; Ong, L.T.; Schoder, H.; Singh-Kandah, S.; Abbate, K.T.; Postow, M.A.; Callahan, M.K.; Wolchok, J.; Chapman, P.B.; Panageas, K.S.; et al. A phase 2 trial of everolimus and pasireotide long-acting release in patients with metastatic uveal melanoma. Melanoma Res. 2016, 26, 272-277. [CrossRef]

142. Khalili, J.S.; Yu, X.; Wang, J.; Hayes, B.C.; Davies, M.A.; Lizee, G.; Esmaeli, B.; Woodman, S.E. Combination Small Molecule MEK and PI3K Inhibition Enhances Uveal Melanoma Cell Death in a Mutant GNAQ- and GNA11-Dependent Manner. Clin. Cancer Res. 2012, 18, 4345-4355. [CrossRef]

143. Musi, E.; Ambrosini, G.; De Stanchina, E.; Schwartz, G.K. The Phosphoinositide 3-Kinase $\alpha$ Selective Inhibitor BYL719 Enhances the Effect of the Protein Kinase C Inhibitor AEB071 in GNAQ/GNA11-Mutant Uveal Melanoma Cells. Mol. Cancer Ther. 2014, 13, 1044-1053. [CrossRef]

144. Amirouchene-Angelozzi, N.; Frisch-Dit-Leitz, E.; Carita, G.; Dahmani, A.; Raymondie, C.; Liot, G.; Gentien, D.; Némati, F.; Decaudin, D.; Roman-Roman, S.; et al. The mTOR inhibitor Everolimus synergizes with the PI3K inhibitor GDC0941 to enhance anti-tumor efficacy in uveal melanoma. Oncotarget 2016, 7, 23633-23646. [CrossRef]

145. Bhatia, S.; Moon, J.; Margolin, K.A.; Weber, J.S.; Lao, C.D.; Othus, M.; Aparicio, A.M.; Ribas, A.; Sondak, V.K. Phase II Trial of Sorafenib in Combination with Carboplatin and Paclitaxel in Patients with Metastatic Uveal Melanoma: SWOG S0512. PLoS ONE 2012, 7, e48787. [CrossRef]

146. Scheulen, M.E.; Kaempgen, E.; Keilholz, U.; Heinzerling, L.; Ochsenreither, S.; Abendroth, A.; Hilger, R.A.; Grubert, M.; Wetter, A.; Guberina, N.; et al. STREAM: A randomized discontinuation, blinded, placebo-controlled phase II study of sorafenib (S) treatment of chemonaïve patients (pts) with metastatic uveal melanoma (MUM). J. Clin. Oncol. 2017, 35, 9511. [CrossRef]

147. Luke, J.J.; Olson, D.J.; Allred, J.B.; Strand, C.A.; Bao, R.; Zha, Y.; Carll, T.; Labadie, B.W.; Bastos, B.R.; Butler, M.O.; et al. Randomized Phase II Trial and Tumor Mutational Spectrum Analysis from Cabozantinib versus Chemotherapy in Metastatic Uveal Melanoma (Alliance A091201). Clin. Cancer Res. 2020, 26, 804-811. [CrossRef] [PubMed]

148. Feng, X.; Degese, M.S.; Iglesias-Bartolome, R.; Vaque, J.P.; Molinolo, A.A.; Rodrigues, M.; Zaidi, M.R.; Ksander, B.R.; Merlino, G.; Sodhi, A.; et al. Hippo-independent activation of YAP by the GNAQ uveal melanoma oncogene through a trio-regulated rho GTPase signaling circuitry. Cancer Cell 2014, 25, 831-845. [CrossRef]

149. Feng, X.; Arang, N.; Rigiracciolo, D.C.; Lee, J.S.; Yeerna, H.; Wang, Z.; Lubrano, S.; Kishore, A.; Pachter, J.A.; Konig, G.M.; et al. A Platform of Synthetic Lethal Gene Interaction Networks Reveals that the GNAQ Uveal Melanoma Oncogene Controls the Hippo Pathway through FAK. Cancer Cell 2019, 35, 457-472. [CrossRef]

150. Sulzmaier, F.J.; Jean, C.; Schlaepfer, D.D. FAK in cancer: Mechanistic findings and clinical applications. Nat. Rev. Cancer 2014, 14, 598-610. [CrossRef] [PubMed]

151. Serrels, A.; Lund, T.; Serrels, B.; Byron, A.; McPherson, R.C.; von Kriegsheim, A.; Gomez-Cuadrado, L.; Canel, M.; Muir, M.; Ring, J.E.; et al. Nuclear FAK controls chemokine transcription, Tregs, and evasion of anti-tumor immunity. Cell 2015, 163, 160-173. [CrossRef] [PubMed]

152. Paradis, J.S.; Acosta, M.; Saddawi-Konefka, R.; Kishore, A.; Lubrano, S.; Gomes, F.; Arang, N.; Tiago, M.; Coma, S.; Wu, X.; et al. Synthetic Lethal Screens Reveal Cotargeting FAK and MEK as a Multimodal Precision Therapy for GNAQ-Driven Uveal Melanoma. Clin. Cancer Res. 2021, 27, 3190-3200. [CrossRef] 
153. Eskens, F.A.L.M.; Ramos, F.J.; Burger, H.; O’Brien, J.P.; Piera, A.; De Jonge, M.J.A.; Mizui, Y.; Wiemer, E.A.C.; Carreras, M.J.; Baselga, J.; et al. Phase I Pharmacokinetic and Pharmacodynamic Study of the First-in-Class Spliceosome Inhibitor E7107 in Patients with Advanced Solid Tumors. Clin. Cancer Res. 2013, 19, 6296-6304. [CrossRef]

154. Leeksma, A.C.; Derks, I.A.M.; Kasem, M.H.; Kilic, E.; de Klein, A.; Jager, M.J.; van de Loosdrecht, A.A.; Jansen, J.H.; Navrkalova, V.; Faber, L.M.; et al. The Effect of SF3B1 Mutation on the DNA Damage Response and Nonsense-Mediated mRNA Decay in Cancer. Front. Oncol. 2020, 10, 609409. [CrossRef]

155. Seiler, M.; Yoshimi, A.; Darman, R.; Chan, B.; Keaney, G.; Thomas, M.; Agrawal, A.A.; Caleb, B.; Csibi, A.; Sean, E.; et al. H3B-8800, an orally available small-molecule splicing modulator, induces lethality in spliceosome-mutant cancers. Nat. Med. 2018, 24, 497-504. [CrossRef] [PubMed]

156. Ito, K.; Thodima, V.; Carter, J.; Bhagwat, N.; Sivakumar, M.; Grego, A.; Rager, J.; Terai, M.; Sato, T.; Abdel-Wahab, O.; et al. Abstract 1137: PRMT5 inhibition regulates alternative splicing and DNA damage repair pathways in SF3B1 R625G expressing uveal melanoma cells. Cancer Res. 2021, 81, 1137. [CrossRef]

157. Fong, J.Y.; Pignata, L.; Goy, P.A.; Kawabata, K.C.; Lee, S.C.; Koh, C.M.; Musiani, D.; Massignani, E.; Kotini, A.G.; Penson, A.; et al. Therapeutic Targeting of RNA Splicing Catalysis through Inhibition of Protein Arginine Methylation. Cancer Cell 2019, 36, 194-209.e9. [CrossRef] [PubMed]

158. Grimes, J.; Shoushtari, A.N.; Orloff, M.; Khan, S.; Chiuzan, C.; Hsiao, S.J.; McDonnell, D.; Marr, B.P.; Carvajal, R.D. Clinical characteristics of SF3B1 mutant (mut) uveal melanoma (UM) and response to immune checkpoint inhibition (ICI). J. Clin. Oncol. 2021, 39, 9535. [CrossRef]

159. Centore, R.C.; Soares, L.M.; Vaswani, R.G.; Ichikawa, K.; Li, Z.; Fan, H.; Setser, J.; Lahr, D.L.; Zawadzke, L.; Chen, X.; et al. Abstract 1224: Discovery of novel BAF inhibitors for the treatment of transcription factor-driven cancers. Cancer Res. 2021, 81, 1224. [CrossRef]

160. Bigot, J.; Lalanne, A.I.; Lucibello, F.; Gueguen, P.; Houy, A.; Dayot, S.; Ganier, O.; Gilet, J.; Tosello, J.; Nemati, F.; et al. Splicing Patterns in SF3B1-Mutated Uveal Melanoma Generate Shared Immunogenic Tumor-Specific Neoepitopes. Cancer Discov. 2021, 11, 1938-1951. [CrossRef]

161. Scheuermann, J.C.; De Ayala Alonso, A.G.; Oktaba, K.; Ly-Hartig, N.; McGinty, R.K.; Fraterman, S.; Wilm, M.; Muir, T.W.; Müller, J. Histone H2A deubiquitinase activity of the Polycomb repressive complex PR-DUB. Nature 2010, 465, 243-247. [CrossRef]

162. Landreville, S.; Agapova, O.A.; Matatall, K.A.; Kneass, Z.T.; Onken, M.D.; Lee, R.S.; Bowcock, A.M.; Harbour, J.W. Histone Deacetylase Inhibitors Induce Growth Arrest and Differentiation in Uveal Melanoma. Clin. Cancer Res. 2012, 18, 408-416. [CrossRef]

163. Wang, Y.; Liu, M.; Jin, Y.; Jiang, S.; Pan, J. In vitro and in vivo anti-uveal melanoma activity of JSL-1, a novel HDAC inhibitor. Cancer Lett. 2017, 400, 47-60. [CrossRef]

164. Moschos, M.M.; Dettoraki, M.; Androudi, S.; Kalogeropoulos, D.; Lavaris, A.; Garmpis, N.; Damaskos, C.; Garmpi, A.; Tsatsos, M. The Role of Histone Deacetylase Inhibitors in Uveal Melanoma: Current Evidence. Anticancer. Res. 2018, 38, 3817-3824. [CrossRef] [PubMed]

165. Jespersen, H.; Olofsson Bagge, R.; Ullenhag, G.; Carneiro, A.; Helgadottir, H.; Ljuslinder, I.; Levin, M.; All-Eriksson, C.; Andersson, B.; Stierner, U.; et al. Concomitant use of pembrolizumab and entinostat in adult patients with metastatic uveal melanoma (PEMDAC study): Protocol for a multicenter phase II open label study. BMC Cancer 2019, 19, 415. [CrossRef]

166. Jespersen, H.; Bagge, O.R.; Ullenhag, G.; Carneiro, A.; Helgadottir, H.; Ljuslinder, I.; Levin, M.; All-Eriksson, C.; Andersson, B.; Stierner, U.; et al. Phase II multicenter open label study of pembrolizumab and entinostat in adult patients with metastatic uveal melanoma (PEMDAC study). Ann. Oncol. 2019, 30, v907. [CrossRef]

167. Booth, L.; Roberts, J.L.; Sander, C.; Lalani, A.S.; Kirkwood, J.M.; Hancock, J.F.; Poklepovic, A.; Dent, P. Neratinib and entinostat combine to rapidly reduce the expression of K-RAS, N-RAS, G $\alpha q$ and G $\alpha 11$ and kill uveal melanoma cells. Cancer Biol. Ther. 2019, 20, 700-710. [CrossRef] [PubMed]

168. Faião-Flores, F.; Emmons, M.F.; Durante, M.A.; Kinose, F.; Saha, B.; Fang, B.; Koomen, J.M.; Chellappan, S.P.; Maria-Engler, S.S.; Rix, U.; et al. HDAC Inhibition Enhances the In Vivo Efficacy of MEK Inhibitor Therapy in Uveal Melanoma. Clin. Cancer Res. 2019, 25, 5686-5701. [CrossRef] [PubMed]

169. Lafave, L.M.; Béguelin, W.; Koche, R.; Teater, M.; Spitzer, B.; Chramiec, A.; Papalexi, E.; Keller, M.D.; Hricik, T.; Konstantinoff, K.; et al. Loss of BAP1 function leads to EZH2-dependent transformation. Nat. Med. 2015, 21, 1344-1349. [CrossRef] [PubMed]

170. Schoumacher, M.; Le Corre, S.; Houy, A.; Mulugeta, E.; Stern, M.-H.; Roman-Roman, S.; Margueron, R. Uveal melanoma cells are resistant to EZH2 inhibition regardless of BAP1 status. Nat. Med. 2016, 22, 577-578. [CrossRef] [PubMed]

171. Filippakopoulos, P.; Qi, J.; Picaud, S.; Shen, Y.; Smith, W.B.; Fedorov, O.; Morse, E.M.; Keates, T.; Hickman, T.T.; Felletar, I.; et al. Selective inhibition of BET bromodomains. Nature 2010, 468, 1067-1073. [CrossRef] [PubMed]

172. Szczepanski, A.P.; Zhao, Z.; Sosnowski, T.; Goo, Y.A.; Bartom, E.T.; Wang, L. ASXL3 bridges BRD4 to BAP1 complex and governs enhancer activity in small cell lung cancer. Genome Med. 2020, 12, 63. [CrossRef] [PubMed]

173. Parrella, P.; Caballero, O.L.; Sidransky, D.; Merbs, S.L. Detection of c-myc amplification in uveal melanoma by fluorescent in situ hybridization. Investig. Ophthalmol. Vis. Sci. 2001, 42, 1679-1684.

174. Ambrosini, G.; Sawle, A.D.; Musi, E.; Schwartz, G.K. BRD4-targeted therapy induces Myc-independent cytotoxicity in Gnaq/11mutatant uveal melanoma cells. Oncotarget 2015, 6, 33397-33409. [CrossRef] [PubMed] 
175. Chua, V.; Orloff, M.; Teh, J.L.; Sugase, T.; Liao, C.; Purwin, T.J.; Lam, B.Q.; Terai, M.; Ambrosini, G.; Carvajal, R.D.; et al. Stromal fibroblast growth factor 2 reduces the efficacy of bromodomain inhibitors in uveal melanoma. EMBO Mol. Med. 2019, 11 , e9081. [CrossRef] [PubMed]

176. Rago, F.; Elliott, G.; Li, A.; Sprouffske, K.; Kerr, G.; Desplat, A.; Abramowski, D.; Chen, J.T.; Farsidjani, A.; Xiang, K.X.; et al. The Discovery of SWI/SNF Chromatin Remodeling Activity as a Novel and Targetable Dependency in Uveal Melanoma. Mol. Cancer Ther. 2020, 19, 2186-2195. [CrossRef] [PubMed]

177. Shrestha, R.; Nabavi, N.; Lin, Y.Y.; Mo, F.; Anderson, S.; Volik, S.; Adomat, H.H.; Lin, D.; Xue, H.; Dong, X.; et al. BAP1 haploinsufficiency predicts a distinct immunogenic class of malignant peritoneal mesothelioma. Genome Med. 2019, 11, 8. [CrossRef] [PubMed]

178. Louie, B.H.; Kurzrock, R. BAP1: Not just a BRCA1-associated protein. Cancer Treat. Rev. 2020, 90, 102091. [CrossRef]

179. Peña-Llopis, S.; Vega-Rubín-De-Celis, S.; Liao, A.; Leng, N.; Pavía-Jiménez, A.; Wang, S.; Yamasaki, T.; Zhrebker, L.; Sivanand, S.; Spence, P.; et al. BAP1 loss defines a new class of renal cell carcinoma. Nat. Genet. 2012, 44, 751-759. [CrossRef]

180. Hanpude, P.; Massengill, J.B.; Cebulla, C.M.; Davidorf, F.; Abdel-Rahman, M.H. BAP1 status and response to radiation in melanoma. Investig. Ophthalmol. Vis. Sci. 2021, 62, 2872.

181. Augsburger, J.J.; Corrêa, Z.M.; Augsburger, B.D. Frequency and Implications of Discordant Gene Expression Profile Class in Posterior Uveal Melanomas Sampled by Fine Needle Aspiration Biopsy. Am. J. Ophthalmol. 2015, 159, 248-256. [CrossRef] [PubMed]

182. Jin, E.; Burnier, J.V. Liquid Biopsy in Uveal Melanoma: Are We There Yet? Ocul. Oncol. Pathol. 2021, 7, 1-16. [CrossRef] [PubMed]

183. Tobal, K.; Sherman, L.S.; Foss, A.J.; Lightman, S.L. Detection of melanocytes from uveal melanoma in peripheral blood using the polymerase chain reaction. Investig. Ophthalmol. Vis. Sci. 1993, 34, 2622-2625.

184. Bidard, F.C.; Madic, J.; Mariani, P.; Piperno-Neumann, S.; Rampanou, A.; Servois, V.; Cassoux, N.; Desjardins, L.; Milder, M.; Vaucher, I.; et al. Detection rate and prognostic value of circulating tumor cells and circulating tumor DNA in metastatic uveal melanoma. Int. J. Cancer 2014, 134, 1207-1213. [CrossRef] [PubMed]

185. Bande, M.F.; Santiago, M.; Muinelo-Romay, L.; Blanco, M.J.; Mera, P.; Capeans, C.; Pardo, M.; Piñeiro, A. Detection of circulating melanoma cells in choroidal melanocytic lesions. BMC Res. Notes 2015, 8, 452. [CrossRef] [PubMed]

186. Anand, K.; Roszik, J.; Gombos, D.; Upshaw, J.; Sarli, V.; Meas, S.; Lucci, A.; Hall, C.; Patel, S. Pilot Study of Circulating Tumor Cells in Early-Stage and Metastatic Uveal Melanoma. Cancers 2019, 11, 856. [CrossRef]

187. Mazzini, C.; Pinzani, P.; Salvianti, F.; Scatena, C.; Paglierani, M.; Ucci, F.; Pazzagli, M.; Massi, D. Circulating Tumor Cells Detection and Counting in Uveal Melanomas by a Filtration-Based Method. Cancers 2014, 6, 323-332. [CrossRef] [PubMed]

188. Callejo, S.A.; Antecka, E.; Blanco, P.L.; Edelstein, C.; Burnier, M.N. Identification of circulating malignant cells and its correlation with prognostic factors and treatment in uveal melanoma. A prospective longitudinal study. Eye 2007, 21, 752-759. [CrossRef]

189. Tura, A.; Lüke, J.; Merz, H.; Reinsberg, M.; Lüke, M.; Jager, M.J.; Grisanti, S. Identification of Circulating Melanoma Cells in Uveal Melanoma Patients by Dual-Marker Immunoenrichment. Investig. Opthalmology Vis. Sci. 2014, 55, 4395. [CrossRef] [PubMed]

190. Terai, M.; Mu, Z.; Eschelman, D.J.; Gonsalves, C.F.; Kageyama, K.; Chervoneva, I.; Orloff, M.; Weight, R.; Mastrangelo, M.J.; Cristofanilli, M.; et al. Arterial Blood, Rather Than Venous Blood, is a Better Source for Circulating Melanoma Cells. EBioMedicine 2015, 2, 1821-1826. [CrossRef] [PubMed]

191. Madic, J.; Piperno-Neumann, S.; Servois, V.; Rampanou, A.; Milder, M.; Trouiller, B.; Gentien, D.; Saada, S.; Assayag, F.; Thuleau, A.; et al. Pyrophosphorolysis-Activated Polymerization Detects Circulating Tumor DNA in Metastatic Uveal Melanoma. Clin. Cancer Res. 2012, 18, 3934-3941. [CrossRef] [PubMed]

192. Metz, C.H.D.; Scheulen, M.; Bornfeld, N.; Lohmann, D.; Zeschnigk, M. Ultradeep sequencing detects GNAQ and GNA11 mutations in cell-free DNA from plasma of patients with uveal melanoma. Cancer Med. 2013, 2, 208-215. [CrossRef] [PubMed]

193. Park, J.J.; Diefenbach, R.J.; Byrne, N.; Long, G.V.; Scolyer, R.A.; Gray, E.S.; Carlino, M.S.; Rizos, H. Circulating Tumor DNA Reflects Uveal Melanoma Responses to Protein Kinase C Inhibition. Cancers 2021, 13, 1740. [CrossRef] [PubMed]

194. Shoushtari, A.N.; Collins, L.; Espinosa, E.; Sethi, H.; Stanhope, S.; Abdullah, S.; Ikeguchi, A.; Ranade, K.; Hamid, O. 1757O Early reduction in ctDNA, regardless of best RECIST response, is associated with overall survival (OS) on tebentafusp in previously treated metastatic uveal melanoma (mUM) patients. Ann. Oncol. 2021, 32, S1210. [CrossRef]

195. Ragusa, M.; Barbagallo, C.; Statello, L.; Caltabiano, R.; Russo, A.; Puzzo, L.; Avitabile, T.; Longo, A.; Toro, M.D.; Barbagallo, D.; et al. miRNA profiling in vitreous humor, vitreal exosomes and serum from uveal melanoma patients: Pathological and diagnostic implications. Cancer Biol. Ther. 2015, 16, 1387-1396. [CrossRef]

196. Achberger, S.; Aldrich, W.; Tubbs, R.; Crabb, J.W.; Singh, A.D.; Triozzi, P.L. Circulating immune cell and microRNA in patients with uveal melanoma developing metastatic disease. Mol. Immunol. 2014, 58, 182-186. [CrossRef] [PubMed]

197. Russo, A.; Caltabiano, R.; Longo, A.; Avitabile, T.; Franco, L.M.; Bonfiglio, V.; Puzzo, L.; Reibaldi, M. Increased Levels of miRNA-146a in Serum and Histologic Samples of Patients with Uveal Melanoma. Front. Pharmacol. 2016, 7, 424. [CrossRef] [PubMed]

198. Stark, M.S.; Gray, E.S.; Isaacs, T.; Chen, F.K.; Millward, M.; McEvoy, A.; Zaenker, P.; Ziman, M.; Soyer, H.P.; Glasson, W.J.; et al. A Panel of Circulating MicroRNAs Detects Uveal Melanoma with High Precision. Transl. Vis. Sci. Technol. 2019, 8, 12. [CrossRef] [PubMed]

199. Radhakrishnan, A.; Badhrinarayanan, N.; Biswas, J.; Krishnakumar, S. Analysis of chromosomal aberration (1, 3, and 8) and association of microRNAs in uveal melanoma. Mol. Vis. 2009, 15, 2146-2154. [PubMed] 
200. Venza, M.; Dell'Aversana, C.; Visalli, M.; Altucci, L.; Teti, D.; Venza, I. Identification of microRNA expression patterns in cutaneous and uveal melanoma cell lines. Tumori 2014, 100, e4-e7. [CrossRef] [PubMed]

201. Eldh, M.; Olofsson Bagge, R.; Lässer, C.; Svanvik, J.; Sjöstrand, M.; Mattsson, J.; Lindnér, P.; Choi, D.-S.; Gho, Y.S.; Lötvall, J. MicroRNA in exosomes isolated directly from the liver circulation in patients with metastatic uveal melanoma. BMC Cancer 2014, 14, 962. [CrossRef] [PubMed]

202. Abdel-Rahman, M.H.; Cebulla, C.M.; Verma, V.; Christopher, B.N.; Carson, W.E.; Olencki, T.; Davidorf, F.H. Monosomy 3 status of uveal melanoma metastases is associated with rapidly progressive tumors and short survival. Exp. Eye Res. 2012, 100 , 26-31. [CrossRef] 